OPEN ACCESS

Edited by:

Alireza Seidavi,

Islamic Azad University, Rasht

Branch, Iran

Reviewed by:

F. Capela e Silva,

Universidade de Évora, Portugal

Shad Mahfuz,

Sylhet Agricultural

University, Bangladesh

*Correspondence:

Youssef A. Attia

yaattia@kau.edu.sa

Mahmoud M. Alagawany

dr.mahmoud.alagwany@gmail.com

Mohammed A. Al-Harth

malharthi@kau.edu.sa

Mohamed E. Abd El-Hack

dr.mahamed.e.abdalhaq@gmail.com

Specialty section:

This article was submitted to Animal Nutrition and Metabolism,

a section of the journal

Frontiers in Veterinary Science

Received: 16 June 2020

Accepted: 09 September 2020

Published: 20 October 2020

Citation:

Attia YA, Alagawany MM, Farag MR,

Alkhatib FM, Khafaga $A F$,

Abdel-Moneim A-ME, Asiry KA, Mesalam NM, Shafi ME, Al-Harthi MA

and Abd El-Hack ME (2020)

Phytogenic Products and

Phytochemicals as a Candidate

Strategy to Improve Tolerance to

Coronavirus.

Front. Vet. Sci. 7:573159.

doi: 10.3389/fvets.2020.573159

\section{Phytogenic Products and Phytochemicals as a Candidate Strategy to Improve Tolerance to Coronavirus}

\author{
Youssef A. Attia ${ }^{1,2,3 *}$, Mahmoud M. Alagawany ${ }^{4 *}$, Mayada R. Farag ${ }^{5}$, Fatmah M. Alkhatib 6 , \\ Asmaa F. Khafaga ${ }^{7}$, Abdel-Moneim Eid Abdel-Moneim ${ }^{8}$, Khalid A. Asiry ${ }^{1}$, \\ Noura M. Mesalam ${ }^{8}$, Manal E. Shafi ${ }^{9}$, Mohammed A. Al-Harthi ${ }^{1 *}$ and \\ Mohamed E. Abd El-Hack ${ }^{4 *}$
}

\begin{abstract}
${ }^{1}$ Agriculture Department, Faculty of Environmental Sciences, King Abdulaziz University, Jeddah, Saudi Arabia, ${ }^{2}$ The Strategic Center to Kingdom Vision Realization, King Abdulaziz University, Jeddah, Saudi Arabia, ${ }^{3}$ Animal and Poultry Production Department, Faculty of Agriculture, Damanhour University, Damanhour, Egypt, ${ }^{4}$ Department of Poultry, Faculty of Agriculture, Zagazig University, Zagazig, Egypt, ${ }^{5}$ Forensic Medicine and Toxicology Department, Faculty of Veterinary Medicine, Zagazig University, Zagazig, Egypt, ${ }^{6}$ Chemistry Department, Faculty of Applied Science, UmmAl-Qura University, Makkah, Saudi Arabia, ${ }^{7}$ Department of Pathology, Faculty of Veterinary Medicine, Alexandria University, Edfina, Egypt, ${ }^{8}$ Biological Application Department, Nuclear Research Center, Atomic Energy Authority, Abu-Zaabal, Egypt, ${ }^{9}$ Department of Biological Sciences, Zoology, King Abdulaziz University, Jeddah, Saudi Arabia
\end{abstract}

Coronaviruses are the causative agents of many infectious diseases in human and animals. These included severe acute respiratory syndrome (SARS), avian infectious bronchitis (IBV) in poultry, Middle East respiratory syndrome (MERS), and coronavirus disease 2019 (COVID-19) in humans. These results had considerable death burdens and negative influences on social-economic life. Since the appearance of the outbreak of the COVID-19 pandemic, continuous investigations have been carried out by researchers to find active compounds, mainly from plants, as natural sources, that could inhibit or stop the proliferation of the causative agent of COVID-19 (SARS-CoV-2). The most common symptoms caused by infections with COVID-19 can include cough, fever, and sore throat. Nevertheless, there is a shortage of active antiviral compounds for treating different strains of coronavirus. Herbal medicine is a class of medication that originates from nature and is aimed at decreasing the use of preservatives, excipients, or other additives and, consequently, lesser side effects. The rapid spread of COVID-19 infection besides the lack of knowledge about any treatments and the growing concern of the public from the virus directed us toward writing this review article in an aim to provide alternatives to the allopathic medicine use. There is a wealth of chemical diversity in the naturally existing compounds, including their antiviral activities, which may encourage their utilization as therapeutics against viral infections, including coronaviruses. The majority of publications on the herbal remedies of coronavirus, MERS, or SARS focused primarily on the use of polar compounds. These substances displayed encouraging inhibitory influences on coronavirus in humans. These include psoralidin, scutellarein, silvestrol, tryptanthrin, caffeic acid, quercetin, myricetin, saikosaponin B2, griffithsin (lectins), and isobavachalcone. Some other agents like lycorine may be useful, 
if the antiviral activity is obtained by concentrations below the toxic plasma levels. According to the available literatures, the most promising inhibitors of coronaviruses are polyphenolic compounds, which are small molecules with conjugated fused ring structures.

Keywords: SARS-CoV-2, COVID-19, phytogenic additive, phytochemicals, health, immunity

\section{INTRODUCTION}

Since the emergence of the recent surpassing COVID-19 disease and the proclamation of the World Health Organization of it as a pandemic on March 11, 2020, the global scientific concern has been prompted. Worldwide, the pandemic has recorded, as of September 4, 2020, 26,504,030 cases, with 873,821 deaths, and the numbers continue to increase drastically ${ }^{1}$. Coronaviruses (CoVs) are positive-sense single-stranded ribonucleic acid (RNA), large (genome size 26-32 kb), and enveloped viruses that fit to the Coronaviridae family and Coronavirinae subfamily. They can infect both humans and animals (1). Coronaviruses are allocated, based on their genotypes and serotypes, into four genera. These are alphacoronavirus ( $\alpha-\mathrm{CoVs})$, betacoronavirus ( $\beta-\mathrm{CoVs})$, gammacoronavirus $(\gamma$-CoVs), and delta coronavirus $(\Delta-\mathrm{CoVs})$ $(2,3)$. All identified coronaviruses that have the potential to infect humanity belong to $\alpha-\mathrm{CoVs}$ and $\beta$-CoVs, including HKU1, HCoV-NL63, HCoV-229E, HCoV-OC43, MERS-CoV, SARS-CoV, and SARS-CoV-2 (2). In the last two decades, two epidemics, and one pandemic caused by $\beta$-CoVs have emerged, namely, SARS, MERS, and COVID-19, respectively (4).

A global threat emerged in Southern China in 2002 due to the emergence of SARS-CoV that infected 8,098 people with 774 mortalities recorded $(3,5)$. Furthermore, in 2012, a regional epidemic in the Middle East occurred as a result of the infection with MERS-CoV, causing 2,494 infections and 858 deaths (6). Recently, on December 31, 2019, a new virus that caused the emergence of COVID-19 disease has been identified in Wuhan, China, and it was named SARS-CoV-2 because nearly $70 \%$ of its genome is identical to that of SARS-CoV $(7,8)$. The main targets of SARS-CoV-2 medications include RNA-based RNA polymerase, papain-like protease $\left(\mathrm{PL}^{\mathrm{pro}}\right)$, 3-chymotrypsin-like protease (3CL ${ }^{\text {pro }}$ ), and spike glycoprotein proteins (S protein).

The spike glycoprotein protein (S protein) helps SARSCoV-2 to invade the human cells as the entry point of the virus is the direct interaction between $S$ proteins and human angiotensin-converting enzyme 2 (hACE2) $(7,9)$. As a result of the frantic worldwide race to find an effective vaccine or cure, several synthetic and natural compounds, as well as antiviral medications, have been proposed to overcome the morbidity and mortality caused by this pandemic. Chloroquine phosphate and hydroxychloroquine were primarily suggested to treat severe cases based on several of their mechanisms of action. These included alkalization of cellular phagolysosomes $(10,11)$. These included remdesivir, arbidol, and lopinavir as antiviral medications, peptide EK1, neuraminidase

${ }^{1}$ https://www.worldometers.info/coronavirus/ inhibitors, and nucleoside analogs which were then suggested as encouraging agents for SARS-CoV-2 (12-16).

The transmission and replication cycle of coronavirus and the natural compound inhibitory effects on viral infection is exemplified in Figure 1.

Infections of animal coronaviruses have attracted veterinary attention for nearly a century. However, in the last two decades, the role of animals in generating coronaviruses has been highlighted since the emergence of SARS, MERS, and COVID-19 diseases, which had a zoonotic origin. Hence, animal coronaviruses became important models for studying how this large family of viruses evolves, generating strains with different biological characteristics. Efforts of veterinary scientists to develop effective anti-coronavirus treatments or vaccines against well-known animal coronaviruses, using herbs and/or Western remedies, contribute to the development of potential therapeutic and prophylactic strategies against SARS-CoV-2. Plants are one of the medicinal active compound sources that have been broadly used as treatments for several diseases caused by microbes (17-19). Moreover, purified natural products and traditional herbal medicines may guide the development of more effective substances based on their structure and desired activities. There are many plant bioactive substances cited to have activities as an antifungal (20), antibacterial (21-23), and antiviral (24, 25). The naturally occurring compounds that have been recognized to have antiviral activity can be used as a starting point to find probable bioactive substance candidates against SARS-CoV2. Molecular docking can be employed to predict how the receptor protein interacts with bioactive compounds (ligands) $(26,27)$. Several previous experiments have been carried out to find bioactive substances of plants that have the potential to inhibit and/or to reduce viruses' proliferation (28-30). A recent publication states that nelfinavir (a selective inhibitor of HIV protease), by using molecular docking, is a drug candidate for the possible treatment of COVID-19 by inhibiting the main protease $\left(\mathrm{M}^{\mathrm{pro}}\right)$ (31). This review focuses on introducing available information on phytogenic compounds or extracts that may have therapeutic potential and demonstrate antiviral capabilities to inhibit coronaviruses, hoping to help in suggesting a naturally based drug for SARS-CoV-2.

\section{Traditional Chinese Medicine}

Traditional Chinese herbal medicine (TCHM) therapy is accomplished by mixing some Chinese herbs that have been stipulated by Chinese herbalists relying on Chinese diagnostic patterns of patients' syndrome. Several Chinese herbal prescriptions, such as Yinhuapinggan granule, Lianhua qingwen capsule, and San Wu Huangqin Decoction, have been suggested 


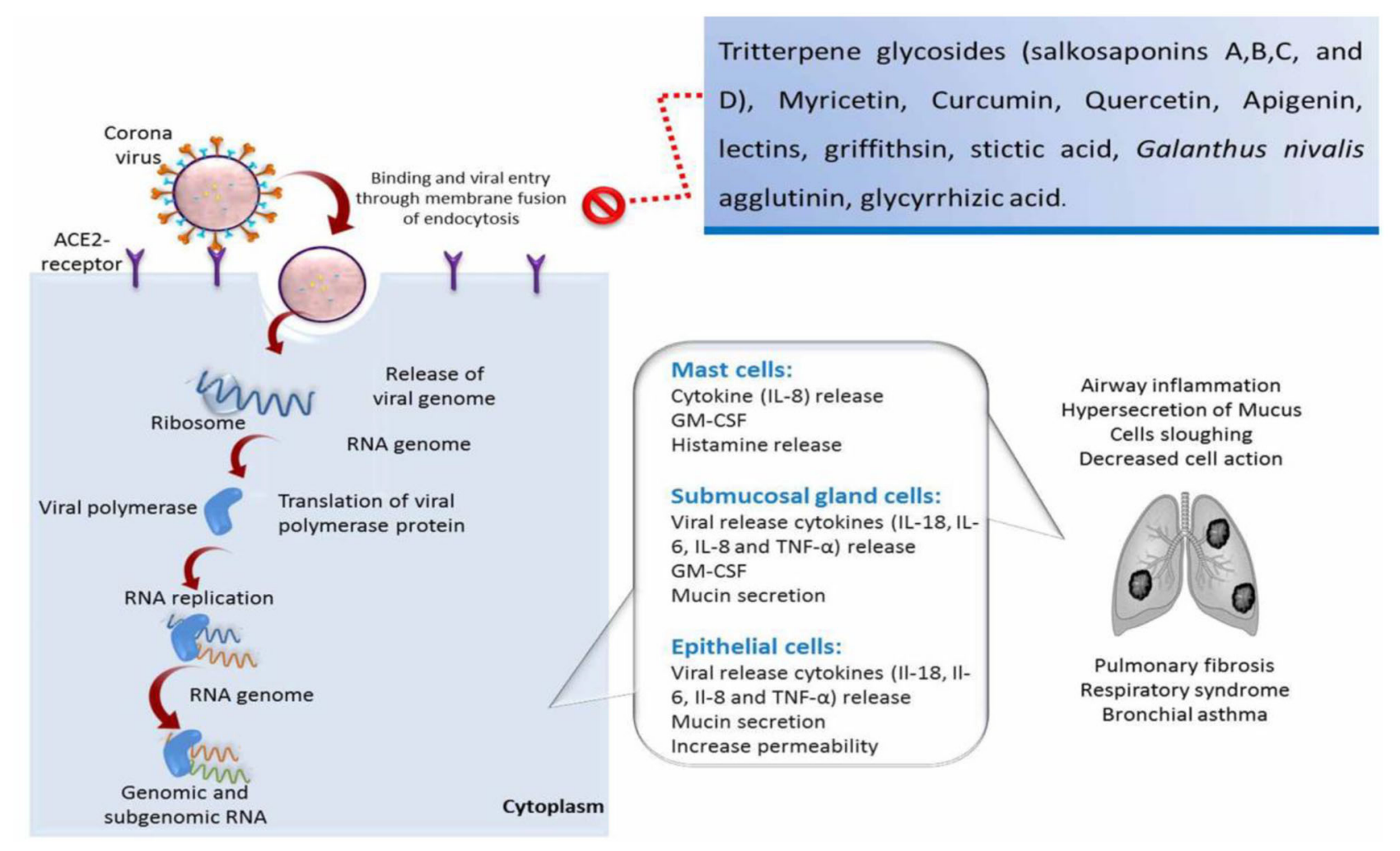

FIGURE 1 | Schematic illustration of the transmission and replication cycle of coronavirus, induction of respiratory syndrome and lung fibrosis, and the natural compound inhibitory effects on viral infection. IL, interleukin; TNF, tumor necrosis factor; GM-CSF, granulocyte-macrophage colony stimulating factor.

to control the replication and proliferation of the viral particles and may thus improve pneumonia caused by influenza viruses (32-34). WHO has invested a lot of works to find out the effectiveness of herbal medicine, since the outbreak of the SARS epidemy in 2002. Treatments of TCHM have proven to be successful in the prevention and treatment of SARS-CoV (3537). Also, the combination of TCHM and western medicine remedies was able to reduce the complications induced by the antibiotic, glucocorticoid, and antiviral therapies $(38,39)$.

After the outbreak of the COVID-19 disease in China, a team of experts was commissioned by the Chinese State Administration of Traditional Chinese Medicine to evaluate the efficacy of the TCHM treatment program. The first case was a patient with TCHM with symptoms, who was cured in Beijing after treatment, which was documented on January 24, 2020. Subsequently, another patient was tested after treatment with TCHM, which prompted a wider application of TCHM for patients with SARS-CoV-2 pneumonia. On January 27, 2020, a report entitled "Diagnosis and Treatment of Pneumonia Caused by Novel Coronavirus Infection (Trial Version 4)" was issued by the Chinese State Administration of TCM and the General Office of the National Health and Health Commission of China which included the updated treatment programs of TCHM (40). These administrations required local and international health committees to implement TCHM treatments and strengthen their integration with western medicine.

\section{The Role of Phytochemicals in Treating Coronavirus}

It is of importance to screen the potential of phytogenic compounds to participate in finding substance candidates, which are able to prevent viral infections (41). Some substances that show violations toward Lipinski's regulation of five (RO5) are epigallocatechingallate (2), pectolinarin (3), hesperidin (3), nelfinavir (1), cannabinoids (2), rhoifolin (3), and bis(3,5,5trimethylhexyl) phthalate (1) (42). Lipinski's rule is tested to assess the drug-likeness and to determine if any specific chemical substance possesses physical and chemical characteristics to be examined as an active drug that can be orally administrated in humans (43). This rule is beneficial because it acts as a basis for the prediction of a high probability of failure or success of one substance with specific biological or pharmacological activity to be developed as a drug. This rule also suggests that if a compound shows two or more range-of-five (RO5) violations, then the substances show low solubility or permeability (44).

Dozens of proteins are coded by coronaviruses, some of which are involved in viral replication and entry into cells, including $3 \mathrm{CL}^{\text {pro }}$ (3-chymotrypsin-like protease; $3 \mathrm{CL}^{\mathrm{pro}}$ ), one of the main proteases of SARS-CoV-2 (9); $\mathrm{M}^{\text {pro }}$, a key enzyme for replication of SARS-CoV-2 (45); and S protein, an essential binding protein for the transmission of SARS-Cov-2 through the cellular membrane via hACE2 (46). The function of $3 \mathrm{CL}^{\text {pro }}$ and $\mathrm{M}^{\mathrm{pro}}$ together is to form a viral replication complex. Therefore, 
$\mathrm{M}^{\text {pro }}, 3 \mathrm{CL}^{\mathrm{pro}}$, and $\mathrm{S}$ protein are ideal targets for researchers and drug developers to design and develop an effective cure for COVID-19 (9).

Furthermore, Coutard et al. (47) suggested an inhibitor for furin, because the $S$ protein sequence has a specific furinlike cleavage.

The inhibition activities of phytochemical agents against $M^{\text {pro }}$ and $S$ proteins have been cited, and some of these compounds are shown in Table 1.

For instance, herbacetin, epigallocatechingallate, rhoifolin, pectolinarin, hesperidin, cannabinoids, and morin showed better docking poses than did nelfinavir, hydroxychloroquine sulfate, and chloroquine (43). Nevertheless, these substances have low oral bioavailability except a few of them, i.e., pectolinarin, epigallocatechingallate, myristicin, and eugenol (Table 1). The low oral bioavailability of these substances illustrates a real problem for drug designers. The substances may have high effectiveness in in vivo and/or in vitro studies; it may fail as a new drug, when considered in clinical trials, besides the oral availability of some compounds, which may decrease if combined with food (48). Therefore, the oral bioavailability of phytogenic compounds must be taken into consideration, when predicting them as candidate drugs.

Limited studies have evaluated the potential of some plantderived compounds for inhibiting $\mathrm{M}^{\text {pro }}$ and S protein of SARSCoV-2 using the molecular docking method. These studies are essential in facilitating subsequent in vitro and in vivo investigations either in clinical trials on humans or in animal models. Hesperidin, the principal flavanone glycoside in the citrus peel, has been cited to be better than nelfinavir (49) with a docking ratio of $S$ protein and $\mathrm{M}^{\text {pro }}$ ranging from -8.3 to -13.51 and -9.6 to -10.4 , respectively $(42,50)$. Moreover, Chen et al. (51) revealed that the best hesperidin position against SARS-CoV-2 3CL ${ }^{\text {pro }}$ was -10.1 . Also, the active compounds of Cannabis sativa and C. indica, namely, cannabinoids, recorded a docking score against $\mathrm{S}$ protein and $\mathrm{M}^{\text {pro }}$ of -8 and -10.2 , respectively (42). Cannabinoids have been described as effective anti-inflammatory (52) and anti-herpes simplex virus agents (53).

Epigallocatechingallate is established in high quantity in green tea (54). The best binding position of this compound against $M^{\text {pro }}$ was -7.8 , and that against $S$ protein was -9.8 . Earlier studies have stated the ability of epigallocatechingallate to restrain the proteolytic potential of SARS-CoV 3CL pro (55). Herbacetin, which can be originating from Rhodiola sp. (golden root), has antiviral activity against vesicular stomatitis virus, a prototype of negative-strand RNA viruses, such as rabies viruses and influenza (56). Table 2 summarizes the antiviral activities of some herbal plants and their derivatives against human coronaviruses.

It has also been cited that herbacetin might act as an inhibitor of MERS-CoV/3CL ${ }^{\text {pro }}$ (69). The docking scores of this compound against S protein, $\mathrm{M}^{\text {pro }}$, and SARS-3CL ${ }^{\text {pro }}$ were $-8.3,-7.2$, and -9.263 , respectively $(42,70)$. The same authors recorded the docking score (a mathematical equation employed to approximately establish the binding affinity between two molecules after they have been docked) of rhoifolin, a flavon found in fresh leaves of Rhus succedanea and Citrus grandis, against S protein, $\mathrm{M}^{\mathrm{pro}}$, and SARS-CoV $3 \mathrm{CL}^{\mathrm{pro}}$, and it was -9.5 , -8.2 , and -9.565 , respectively. The induced-fit docking results of pectolinarin and morin against SARS-CoV 3CL ${ }^{\text {pro }}$ were -8.054 and $-8,930$ (70), respectively; however, the best pose between these compounds and $S$ protein was -9.8 and -8.8 , and -7.8 and -8.2 with $\mathrm{M}^{\text {pro }}$, respectively (42). Pectolinarin can be found in plume thistles (Cirsium spp.), while almond, guava, and old fustic contain a high quantity of morin. The best position of kaempferol, a phytochemical found in spinach and kale, against $S$ protein and $\mathrm{M}^{\text {pro }}$ was -8.5 and $-7.8(41)$ ), while -8.526 was the best binding position of this compound against SARS-CoV $3 \mathrm{CL}^{\text {pro }}(70)$.

\section{Virtual Screening of SARS-CoV-2 Inhibitors}

Due to the limited time, since the emergence and spread of the COVID-19 pandemic, studies conducted on SARSCoV-2 are minimal; however, several computer modeling studies for screening purposes are available (57, 58). Despite the difficulty of obtaining consistent output through various modeling approaches, computer modeling nonetheless provides the opportunity to compare the relative binding affinity of a molecular bank concerning the intended receptor (71-73). Computer modeling may also be of specific value due to its speed and versatility. This precipitates the prospect of finding a potent inhibitor of SARS-CoV-2 instead of relying on the conventional physical selection of large banks for bioactivity of plant extracts or phytochemicals. This consumes a long time and high costs (74). The highlighted compounds by computer modeling can then be redirected to cell-based tests to evaluate their in vitro toxicity and efficacy, before being used in animal model experiments or human clinical trials. For instance, among 83 compounds found in TCHM virtually screened by Lung et al. (58), flavin, an antioxidant polyphenolic compound, has been identified as a potential inhibitor against SARS-CoV-2 RNAdependent RNA polymerase.

Moreover, Zhang et al. (57) selected 13 compounds for further investigations as potential inhibitors for SARS-CoV-2 of 115 compounds tested in TCHM that have been virtually tested. Many of these polyphenol candidates, such as quercetin and kaempferol, are naturally present and can be considered as treatments for other diseases $(75,76)$. Nevertheless, there are many doubts about the potential lack of efficacy of some polyphenols and traditional herbal medicines that are promoted to treat the symptoms of COVID-19. For example, however, the TCHM called Lianhuaqingwen demonstrated antiviral potential against SARS-CoV-2, with quite higher $\mathrm{EC}_{50}$ when compared to the commercial drug remdesivir ( $\sim 411$ vs. $0.39 \mu \mathrm{g} / \mathrm{mL}$, respectively) using the same method (77). The major polyphenolic drugs able targets of SARS-CoV-2 are depicted in Figure 2.

\section{SARS-CoV Inhibitors}

Due to the limited available publications on COVID-19, some publications and research articles that have been searching for SARS-CoV inhibitors can represent a good starting point to identify the competency antiviral agents against SARS-CoV-2. Therefore, it is necessary to review the antiviral agents that were 
TABLE 1 | List of plant-derived compounds and their molecular docking analysis against $\mathrm{M}^{\text {pro }} / 3 \mathrm{CL}^{\text {pro }}$ (6LU7) and S protein (6VXX), chemical structure, oral bioavailability, and sources (42).

\begin{tabular}{|c|c|c|c|c|c|c|}
\hline Compounds & Chemical structure & PubChem CID & $\begin{array}{l}\text { Binding energy } \\
\text { with } \\
M^{\text {pro } / 3 C L^{\text {pro }}}\end{array}$ & $\begin{array}{l}\text { Binding energy } \\
\text { with S protein }\end{array}$ & $\begin{array}{l}\text { Oral } \\
\text { bioavailability }\end{array}$ & Sources \\
\hline Epigallocatechingallate & & 65064 & -7.8 & -9.8 & High & $\begin{array}{l}\text { Green tea (Camellia } \\
\text { sinensis), hazelnut (Corylus } \\
\text { avellana), onion (Allium } \\
\text { cepa), plum (Prunus } \\
\text { domestica), skin of apple } \\
\text { (Malus domestica) }\end{array}$ \\
\hline Myristicin & & 4276 & -5.3 & -6.1 & High & Nutmeg (Myristica fragrans) \\
\hline Cannabinoids & & 9852188 & -8.0 & -10.2 & Low & Marijuana (Cannabis spp.) \\
\hline Hesperidin & & 10621 & -8.3 & -10.4 & Low & $\begin{array}{l}\text { Citrus fruit (Citrus spp.), } \\
\text { yellow toadflax (Linaria } \\
\text { vulgaris), peppermint } \\
\text { (Mentha spp.) }\end{array}$ \\
\hline Rhoifolin & $\mathrm{HO}$ & 5282150 & -8.2 & -9.5 & Low & $\begin{array}{l}\text { Bitter orange (Citrus } \\
\text { aurantium), grape (Vitis } \\
\text { vinifera), bananas (Musa } \\
\text { spp.), lemon (Citrus limon), } \\
\text { grapefruit (Citrus paradisi), } \\
\text { tomato (Lycopersicon } \\
\text { esculentum) }\end{array}$ \\
\hline Eugenol & & 3314 & -5.4 & -6.1 & High & $\begin{array}{l}\text { Clove (Syzygium } \\
\text { aromaticum) }\end{array}$ \\
\hline Tangeretin & $\mathrm{CH}_{3} \mathrm{O}$ & 68077 & -6.5 & -7.9 & Low & Citrus fruit (Citrus spp.) \\
\hline
\end{tabular}


TABLE 1 | Continued

\begin{tabular}{|c|c|c|c|c|c|c|}
\hline Compounds & Chemical structure & PubChem CID & $\begin{array}{l}\text { Binding energy } \\
\text { with } \\
\mathrm{M}^{\text {pro }} / 3 \mathrm{CL}^{\text {pro }}\end{array}$ & $\begin{array}{l}\text { Binding energy } \\
\text { with S protein }\end{array}$ & $\begin{array}{l}\text { Oral } \\
\text { bioavailability }\end{array}$ & Sources \\
\hline Kaempferol & $\mathrm{OH}$ & 5280863 & -7.8 & -8.5 & Low to good & $\begin{array}{l}\text { Broccoli (Brassica oleracea } \\
\text { var. italica), spinach } \\
\text { (Spinacia oleracea), tea } \\
\text { (Camellia sinensis), beans } \\
\text { (Phaseolus vulgaris), Kale } \\
\text { (Brassica oleracea var. } \\
\text { sabellica) }\end{array}$ \\
\hline 6-Shogaol & 0 & 5281794 & -5.8 & -5.5 & Low & Ginger (Zingiber officinale) \\
\hline Chalcone & & 637760 & -6.2 & -7.5 & Very good & Citrus fruit (Citrus spp.) \\
\hline Morin & & 5281670 & -7.8 & -8.8 & Very low & $\begin{array}{l}\text { Guava (Psidium guajava), } \\
\text { almond (Prunus dulcis), } \\
\text { Osage orange (Maclura } \\
\text { pomifera), old fustic } \\
\text { (Chlorophora tinctoria) }\end{array}$ \\
\hline Nobiletin & & 72344 & -6.4 & -8.1 & Low & Citrus fruit (Citrus spp.) \\
\hline Herbacetin & $\mathrm{OH} \mathrm{O}$ & 5280544 & -7.2 & -8.3 & Good & $\begin{array}{l}\text { Common boneset } \\
\text { (Eupatorium perfoliatum), } \\
\text { common horsetail } \\
\text { (Equisetum arvense), } \\
\text { Golden root (Rhodiola spp.), } \\
\text { Gossypium (Gossypium } \\
\text { hirsutum) }\end{array}$ \\
\hline
\end{tabular}


TABLE 1 | Continued

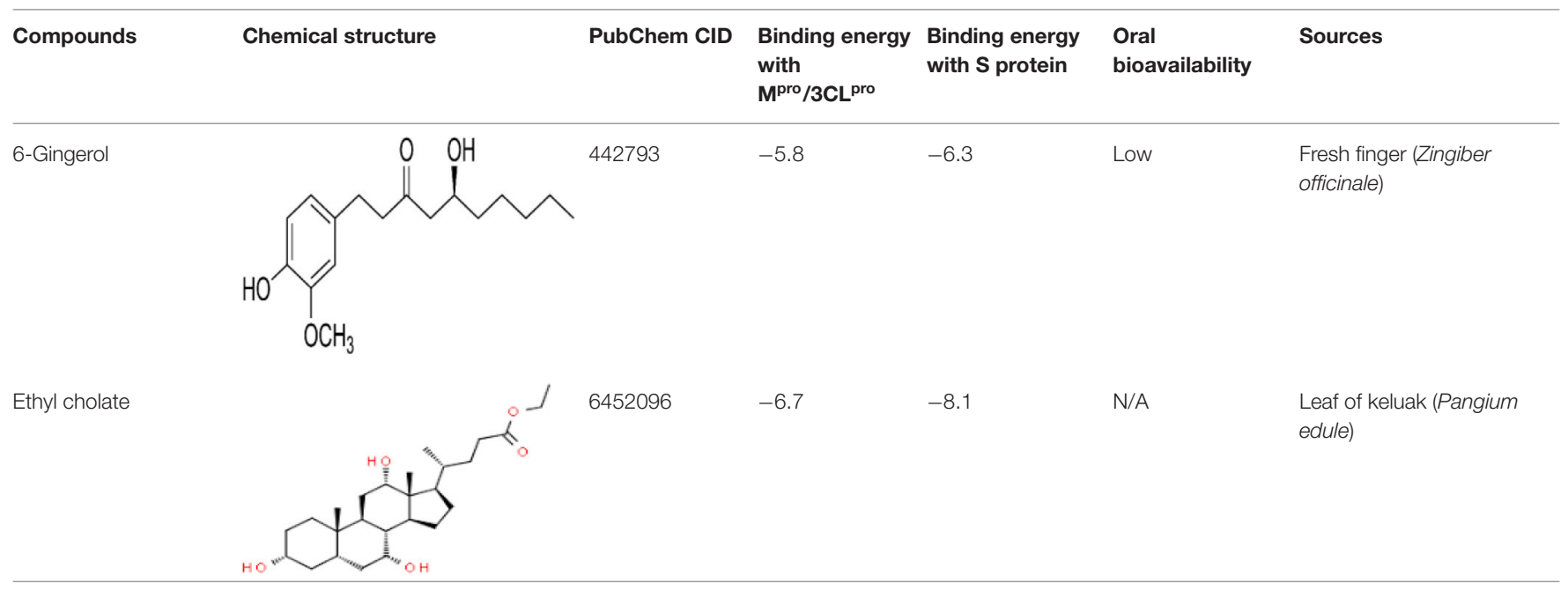

N/A, not applicable.

successful in inhibiting this viral strain and the possibility of their effectiveness against this novel coronavirus. The primary sites of antiviral drug action are clarified in Figure 3.

\section{Virtual Screening}

Virtual computer docking models have been used by several investigators to screen the inhibition activities for prospective phytochemical agents against several binding sites of coronaviruses, including $\mathrm{S}$ protein, RNA-dependent RNA polymerase, papain-like protease $\left(\mathrm{PL}^{\mathrm{pro}}\right)$, and $3 \mathrm{CL}^{\text {pro }}$ $(64,78,79)$. The authors highlighted the antiviral potential of several substances such as sabadinine and aurantiamide acetate as these compounds could inhibit or bind to critical proteins found in SARS-CoV.

\section{Compound Library Screening}

It is noteworthy that searching for natural phytochemicals that have inhibitory activity against SARS-CoV using extensive in vitro screening studies is similar to the search for a "needle in a haystack" $(59,80)$, despite the existence of many such studies. For instance, in the study of Li et al. (59), the authors found that there are only four of Chinese medicinal herbs (Artemisia annua, Pyrrosia lingua, Lycoris radiata, and Lindera aggregata) with moderate to high antiviral efficiency, when they examined more than 200 chloroform or ethanol extracts of these plants. Despite this low number, only one compound (lycorine) with high antiviral efficacy $\left(\mathrm{EC}_{50}\right.$ of $\left.15.7 \pm 1.2 \mathrm{nM}\right)$ derived from Lycoris radiata was allotted as a SARS-CoV prospective medication candidate (59). It is disappointing that lycorine can exert toxicity impacts at relatively low dosage levels $(\sim 1,000$ $\mu \mathrm{g} / \mathrm{kg}$ in dogs), and this is what the authors did not mention $(73,81)$.

SARS-CoV helicase (nsP13) is an enzyme that exerts a vital role in the replication, transcription, and translation of the viral genome. Minimal investigations have studied the efficacy of naturally occurring compounds to inhibit this enzyme. Yu et al. (82) screened the activity of 64 natural substances against
nsP13. They indicated that the most promising candidates were the polyphenolic substances scutellarein ( $\mathrm{IC}_{50} 0.86 \pm$ $0.48 \mu \mathrm{M})$ and myricetin $\left(\mathrm{IC}_{50} 2.71 \pm 0.19 \mu \mathrm{M}\right)$, without any considerable noticeable toxic impact on the normal (nontumorigenic) epithelial cells of the breast. Both compounds were noticed to inhibit nsP13 by inhibiting the activity of ATPase indirectly. Scutellarein has been conventionally considered as an anti-inflammatory agent and used in respiratory infection medication and can be isolated from Chinese Skullcap (Scutellaria baicalensis) (83). Myricetin is cited in vegetables such as garlic and Calamus scipionum and fruits such as cranberry in rationally high concentrations $(84,85)$.

\section{Phenolic Compounds}

Polyphenols are a class of mainly natural compounds that have shown antiviral properties across several investigations. For instance, the effectiveness of Psoralea corylifolia seeds against SARS-CoVPL ${ }^{\text {ro }}$ has been ascribed to the bioactive agents of ethanolic extract of this plant (polyphenolic compounds), in a bioassay-guided fractionation way (48). From the ethanolic extract, six polyphenols that vary widely in their antiviral activities ( $\mathrm{IC}_{50}$ values between 4,200 and $38,400 \mathrm{nM}$ ) were isolated and identified as neobavaisoflavone, corylifol A, bavachinin, 4'-O-methylbavachalcone, isobavachalcone, and psoralidin. Isobavachalcone and psoralidin demonstrated the highest antiviral activity. When mixed, both compounds showed reversible inhibition of $\mathrm{PL}^{\text {pro }}$ through their ability to attach to the free form of the enzyme preferentially, rather than the complex substrate of the enzyme (type I mechanism) (48).

\section{Quercetin}

Quercetin is a flavonoid that originated in many fruits, grains, and vegetables, but high levels of the active substance were found, particularly in certain herbs and berries $(86,87)$. Several animal and laboratory investigations showed that quercetin may have the 
TABLE 2 | Antiviral activities of herbal plants and their derivatives against human coronaviruses in vitro (cell culture).

\begin{tabular}{|c|c|c|c|c|c|c|}
\hline Plant species & Virus strain* & Extract type & Bioactive compounds & $\begin{array}{l}E_{50} \text { or } I_{50} \\
(\mu \mathrm{g} / \mathrm{mL})\end{array}$ & Mechanism(s) of action & Reference \\
\hline CTM & SARS-CoV-2 & ND & $\begin{array}{l}\text { Betulinic acid, } \\
\text { coumaroyltyramine, } \\
\text { kaempferol, lignan, } \\
\text { desmethoxyreserpine, } \\
\text { cryptotanshinone, } \\
\text { dihomo-c-linolenic, } \\
\text { dihydrotanshinone, } \\
\text { moupinamide, } \\
\text { N-cis-feruloyltyramine, } \\
\text { quercetin, sugiol }\end{array}$ & ND & $\begin{array}{l}\text { Reduce viral replication } \\
\text { Inhibition of } 3 C L^{\text {pro }} \text { and } P L^{\text {pro }} \\
\text { Inhibition of cellular entry and } \\
\text { spike protein }\end{array}$ & $(57)$ \\
\hline Camellia sinensis & SARS-CoV-2 & ND & Theaflavin & & $\begin{array}{l}\text { Binding to RNA-dependent RNA } \\
\text { polymerase }\end{array}$ & (58) \\
\hline $\begin{array}{l}\text { Artemisia annua } \\
\text { Lindera aggregata } \\
\text { Lycoris radiata }\end{array}$ & $\begin{array}{l}\text { SARS-CoV (BJ001 } \\
\text { and BJ006) }\end{array}$ & Ethanol extract (95\%) & Lycorine in L. radiata & $\begin{array}{l}34.5-39.2 \\
80.6-88.2 \\
2.1-2.4\end{array}$ & Not determined & (59) \\
\hline Toona sinensis & SARS-CoV FFM1 & $\begin{array}{l}\text { Boiled water extract } \\
\text { of leaves }\end{array}$ & Not determined & $30-43$ & Not determined & (60) \\
\hline Glycyrrhizae radix & SARS-CoV FFM1 & $\begin{array}{l}\text { Used chemical } \\
\text { standards }\end{array}$ & $\begin{array}{l}\text { Glycyrrhizin } \\
18 \beta \text {-Glycyrrhetinic acid }\end{array}$ & $365 \pm 12 \mu \mathrm{M}$ & Not determined & $(61)$ \\
\hline $\begin{array}{l}\text { Barometz } \\
\text { Gentiana scabra } \\
\text { Dioscorea batatas } \\
\text { Cassia tora } \\
\text { Taxillus chinensis }\end{array}$ & $\begin{array}{l}\text { SARS-CoV } \\
\text { (Hong Kong strain) }\end{array}$ & Ethanol extract (75\%) & $\begin{array}{l}\text { Secoiridoid \& glycoside } \\
\text { Polysaccharides } \\
\text { Emodin } \\
\text { Quercetin }\end{array}$ & $\begin{array}{l}8.70 \\
8.06 \\
8.43 \\
5.39\end{array}$ & Not determined & (62) \\
\hline Urtica dioica & $\begin{array}{l}\text { SARS-CoV Urbani } \\
\text { strain } \\
(200,300,592)\end{array}$ & $\begin{array}{l}\text { Used chemical } \\
\text { standards }\end{array}$ & Urtica dioica agglutinin & $2.6 \pm 3.7 \mu \mathrm{g} / \mathrm{mL}$ & $\begin{array}{l}\text { Inhibition of viral replication in } \\
\text { a dose-dependent Binding to spike } \\
\text { protein of SARS-CoV and } \\
\mathrm{N} \text {-acetylglucosamine-like residues on } \\
\text { the glycosylated envelope }\end{array}$ & (63) \\
\hline Artemisia annua & SARS-CoVCL ${ }^{\text {pro }}$ & ND & Aurantiamide acetate & ND & $\begin{array}{l}\text { Inhibiting the active pocket of CoV } \\
\text { protease }\end{array}$ & (64) \\
\hline Aglaia sp. & $\begin{array}{l}\text { MERS-CoV } \\
\text { EMC/2012 }\end{array}$ & $\begin{array}{l}\text { Used chemical } \\
\text { standards }\end{array}$ & Silvestrol & 1.3 & $\begin{array}{l}\text { Specific inhibitor of RNA helicase } \\
\text { elF4A }\end{array}$ & $(65)$ \\
\hline $\begin{array}{l}\text { Broussonetia } \\
\text { papyrifera }\end{array}$ & MERS-COV PL pro & Ethanol extract & $\begin{array}{l}\text { Kazinol F } \\
\text { Broussochalcone A }\end{array}$ & $\begin{array}{l}39.5 \pm 5.1 \\
42.1 \pm 5.0\end{array}$ & $\begin{array}{l}\text { Non-competitive inhibition of } \\
\text { CoVPL pro }\end{array}$ & $(66)$ \\
\hline Stephania tetrandra & HCoV-OC43 & $\begin{array}{l}\text { Used chemical } \\
\text { standards }\end{array}$ & $\begin{array}{l}\text { Tetrandrine } \\
\text { Fangchinoline } \\
\text { Cepharanthine }\end{array}$ & $\begin{array}{l}0.33 \pm 0.03 \\
\pm 0.07 \\
0.83 \pm 0.07\end{array}$ & $\begin{array}{l}\text { Inhibit viral S and N proteins } \\
\text { expression and viral replication }\end{array}$ & $(67)$ \\
\hline $\begin{array}{l}\text { Strobilanthes cusia } \\
\text { leaf }\end{array}$ & HCoV-NL63 & Methanol extract & $\begin{array}{l}\text { Tryptanthrin } \\
\text { Indigodole B }\end{array}$ & $\begin{array}{l}0.06 \\
2.09\end{array}$ & $\begin{array}{l}\text { Blocking activity of papain-like } \\
\text { protease } 2 \text { and viral RNA } \\
\text { genome synthesis }\end{array}$ & (68) \\
\hline
\end{tabular}

*SARS-CoV-2 results obtained by computer modeling. CTM, Chinese traditional medicines; CLpro, chymotrypsin-like protease; PLpro, papain-like protease; ND, no data.

potential to inhibit a broad spectrum of viruses, including SARS$\mathrm{CoV}$, while quercetin showed a reasonable activity in inhibiting SARS-CoVPL ${ }^{\text {pro }}\left(\mathrm{IC}_{50}\right.$ of $\left.8.6 \pm 3.2 \mu \mathrm{M}\right)(66)$ and SARS-CoV helicase (82). This could be ascribed to its chemical arrangement that is structurally similar to polyphenolics scutellarein and myricetin (82). Furthermore, the potential of quercetin to inhibit viruses may be due to its ability to restore levels of several antioxidants in body tissues. For example, quercetin has shown restoring influence by decreasing the concentrations of several antioxidants in the lungs, including catalase, reduced glutathione, and superoxide dismutase, in mice treated with influenza, suggesting that quercetin taken along with viral infection may safeguard lung tissues and preserve antioxidant capacity
(88). Although providing quercetin orally simultaneously with viral installation did not restore the decrease in the level of vitamin $\mathrm{E}$ connected with a viral infection, it augmented the pulmonary levels of superoxide dismutase, reduced glutathione, and catalase (88).

\section{Lectins}

Plant lectins are naturally occurring proteins that are able to combine reversibly and correctly to carbohydrate groups and show antiviral activity against several viral infections, including herpes simplex virus, Ebola, influenza, and SARS-CoV (8992). Curiously, Michelow et al. (90) reported that increasing recombinant human mannose-binding lectin levels in the plasma 


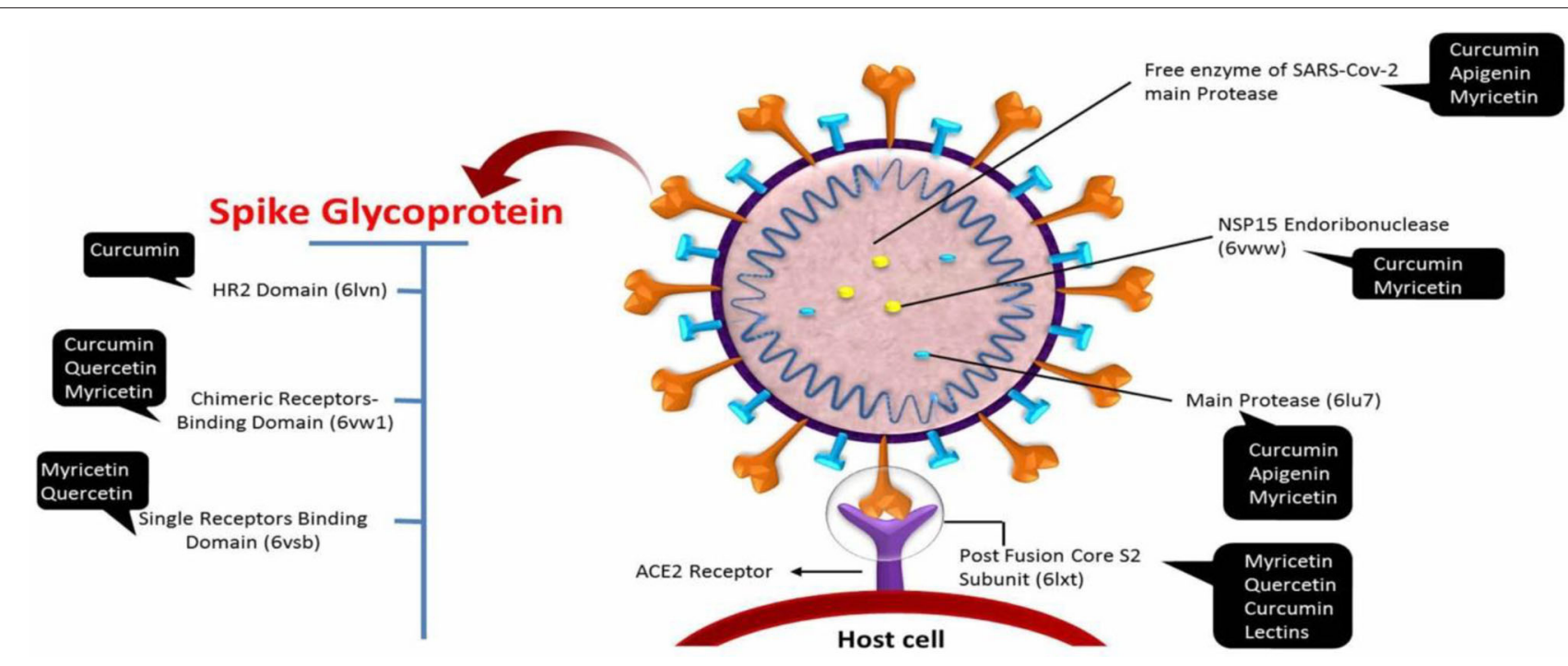

FIGURE 2 | The major drug able targets of SARS-CoV-2.

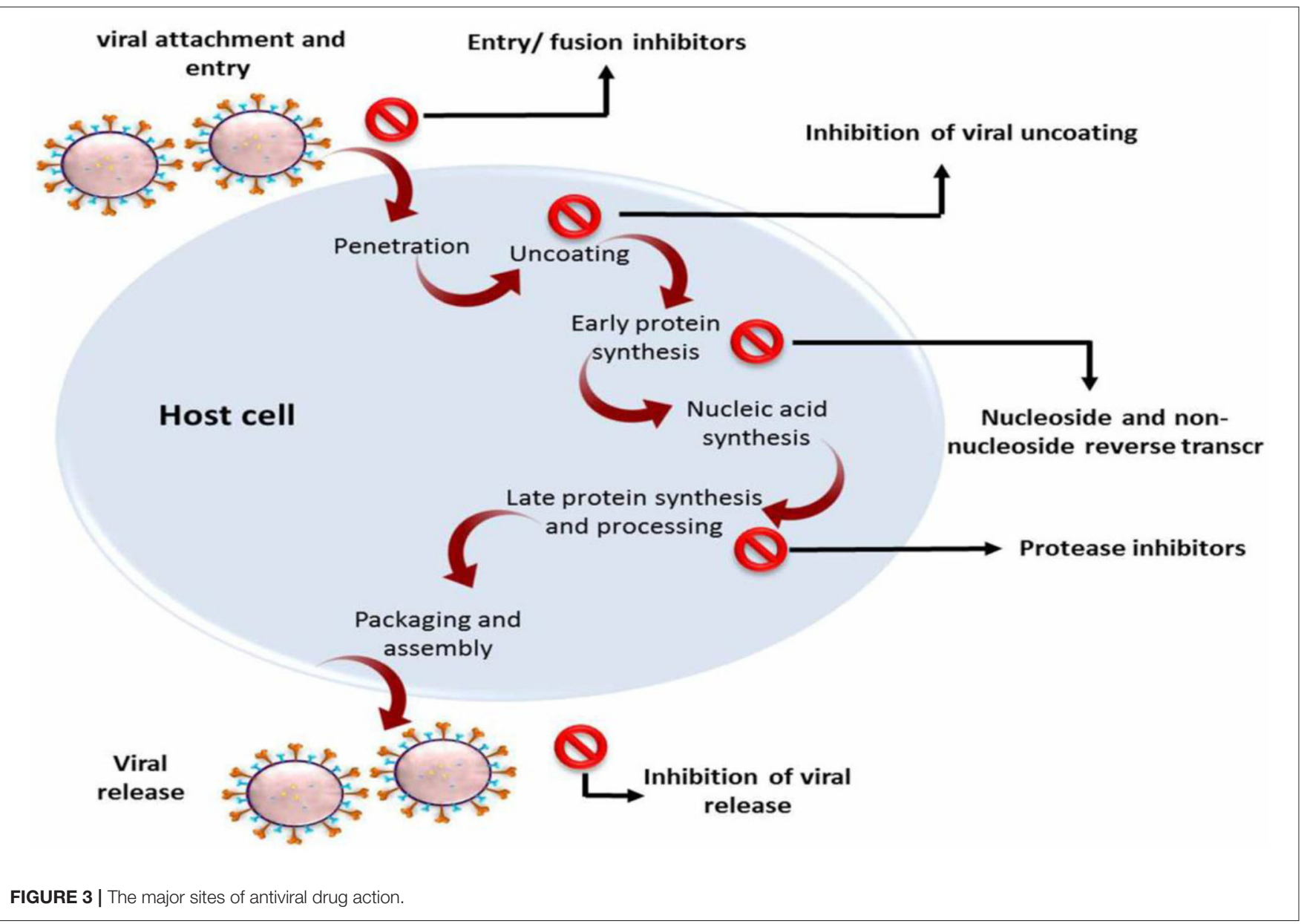

of mice permitted them to overcome different viral infections except the fatal Ebola. Petersen et al. (93) demonstrated that lectins had shown reasonable tolerability in clinical experiments.
Moreover, a total of 33 plant lectins have been tested using a cytopathic effect assay for their antiviral activity against SARS-CoV (94). The authors noticed that $\mathrm{EC}_{50}$ values for Lycoris 
radiata agglutinin were low $(0.45 \pm 0.08 \mu \mathrm{g} / \mathrm{mL})$ and did not influence the virus replication. The exact mechanisms of action for the potential antiviral activity of plant lectins were not established. Therefore, further investigations are required to prospect for a treatment of coronavirus infection among the promising classes of naturally derived substances.

\section{Chemical Modification of Phytochemicals to Increase Their Potency}

As described earlier, several natural derivatives demonstrate considerable promising results as SARS-CoV inhibitors; however, only few fulfill the requirements of the commercial drug in terms of selectivity and efficacy. Hence, increasing the effectiveness and antiviral activity of these compounds to the appropriate levels for therapeutic applications may require adjusting their chemical structure. Moreover, drug developers can reduce timelines and increase their chances to find effective viral inhibitors starting from understanding the structural conformity of the naturally derived compounds. Working on this principle, modification of the main active constituent of liquorice, namely, glycyrrhizin, which has been used in patients treating SARS-CoV (95), might enhance its viral inhibition activity (61). For instance, tomentins A-E (all compounds occur naturally) exhibited substantial inhibitory potential against SARS-CoV in vitro comparison to their non-geranylated precursor substances (96).

Moreover, quercetin has demonstrated antiviral activity against porcine epidemic diarrhea virus (PEDV) less 100 times than quercetin-7-rhamnoside (97). The antiviral activity of glycyrrhizin was also raised by 10 -fold by adding 2 -acetamido- $\beta$ $D$-glucopyranosylamine to its glycoside chain. The enhancement in the antiviral activity can be ascribed to increasing its attraction to the $S$ proteins. Again, in vivo or in vitro route of administrations and duration of the applications should be given. Furthermore, glycyrrhizin conjugation with free $\mathrm{COOH}$ and amino acid residues increased its activity up to 70 -fold, although with a significant decrease in selectivity (73). Although the examples of amendments displayed here differ, it is necessary to not assume that substitutions were randomly supplemented but rather performed to target a particular biochemical pathway and/or receptor. For example, the supplementation of residues of amino acids and glycosides to glycyrrhizin was conducted in request to raise its attraction to the highly glycosylated $S$ proteins of SARS-CoV. Consequently, future investigations seeking to find effective natural inhibitors of SARS-CoV-2 must also take into account investigating the potential designing or modifications of synthetic derivatives that might enhance required activity.

\section{MERS-CoV Inhibitors}

Few investigations have been carried out to determine the therapeutic potential of plant-derived compounds against MERS$\mathrm{CoV}$. Müller et al. (65) in vitro noticed that the replication of MERS-CoV was significantly inhibited by a phytochemical derived from Aglaia sp. called silvestrol. The inhibition of viral replication caused by silvestrol can be recognized to its inhibitory activity of RNA helicase eIF4A, which prevents protein expression of coronavirus and preclude the establishment of replication and transcription complexes (65). Also, the protein obtained from the red algae Griffithsia, which is called griffithsin, can be considered an appropriate inhibitor of MERS-CoV. Griffithsin can inhibit the attachment of MERS-CoV and several human coronaviruses to host cells by specifically binding to glycans of protein spikes of the viruses via its three carbohydratebinding domains $(98,99)$. It is worth noting that griffithsin has a specificity index against human coronavirus cells (compared to human fibroblast or colorectal adenocarcinoma cell lines) established between 30 and 3,100 (98). Therefore, griffithsin can be considered an appropriate candidate for clinical studies as well as animal model experiments against SARS-CoV-2.

\section{Inhibitors of Other Human Coronaviruses}

Several plant-derived compounds have been tested in vivo for their antiviral potential against human coronavirus strains. Saikosaponins (A, B2, C, and D) characterize a group of oleanane derivatives, usually existing as glycosides, which naturally occur in medicinal plants such as Scrophularia scorodonia, Heteromorpha spp., and Bupleurum spp. The antiviral potential of saikosaponins has previously been evaluated against several viruses such as measles virus and hepatitis B virus (100, 101), hepatitis C (102), and HCoV-229E coronavirus strain (103). Saikosaponins (A, B2, C, and D) showed good to moderate antiviral potential against $\mathrm{HCoV}-229 \mathrm{E}$, particularly saikosaponin $\mathrm{B} 2$, which showed the highest efficacy $\left(\mathrm{EC}_{50}\right.$ of 1.7 $\pm 0.1 \mu \mathrm{M})$. The same compound showed inhibitory activity on viral attachment and penetration. It seems that saikosaponin B2 has the potential to display a wide range of bioactivity, including inhibition of cellular entry of hepatitis $\mathrm{C}$ as well as inhibition of drug transporters that are associated with resistance of multidrug and present on the cellular surface $(102,104)$.

The primary bioactive naturally occurring compounds identified in Stephania tetrandra and associated species have been scanned for their antiviral activities against HCoV-OC43 (67). These compounds were cepharanthine, tetrandrine, and fangchinoline, and all of them exhibited antiviral activity with $\mathrm{EC}_{50}$ values of $0.83 \pm 0.07,0.33 \pm 0.03$, and $1.01 \pm 0.07$, respectively (67). The ability of these compounds to inhibit viral-induced apoptosis might be attributed to their potential to suppress the virus-induced host response, virus replication, and viral S protein and nucleocapsid protein ( $\mathrm{N}$ protein) expression. Moreover, tetrandrine can improve the host response induced by the virus by activating the p38 MAPK pathway in MRC- 5 cells.

The viral product of another human coronavirus strain HCoV-NL63 has been decreased (EC 50 of $1.17 \pm 0.75 \mu \mathrm{g} / \mathrm{mL}$ ) by treatment of the ethanolic extracts of Sambucus formosana stems (105). Caffeic acid was the most potent antiviral agent $\left(\mathrm{EC}_{50}\right.$ of $3.54 \pm 0.77 \mu \mathrm{M}$; or $\sim 640 \pm 140 \mathrm{ng} / \mathrm{mL}$ ) identified among the extracts' phenolic compounds. It has been cited that caffeic acid inhibits the attachment of $\mathrm{HCoV}$ and other viruses such as hepatitis B to host cells by the ability to bind to $S$ proteins. Still, the specific binding sites were not identified (106). Notably, extracts from $S$. formosana are likewise non-toxic and suitable for human use as the extracts of Sambucus nigra, another species that belongs to the same genus of S. formosana, have been commercialized to treat symptoms of colds and flu. 
However, clinical studies would be necessary to ensure this. The bioavailability and delivery mechanisms of these extracts must also be taken into consideration to attain therapeutic plasma levels for viral inhibition (107).

The antiviral potential of Strobilanthes cusia leaf's methanolic extract against HCoV-NL63 has been recently stressed by Tsai et al. (107), and the authors have noticed an efficient reduction in virus yield in infected cells $\left(\mathrm{EC}_{50}=0.64 \mu \mathrm{g} / \mathrm{mL}\right)$ in a dosebased manner. The six substantial phytochemicals of the extract have been isolated, purified, and identified, and among them, indigodole $\mathrm{B}$, an indole alkaloid derivative, and tryptanthrin, a natural alkaloid having the basic indoloquinazoline moiety, exhibited the highest antiviral activity $\left(\mathrm{EC}_{50}\right.$ of 2.60 and $1.52 \mu \mathrm{M}$, respectively) against $\mathrm{HCoV}$. The rise in the antiviral potential of tryptanthrin compared to indigodole $\mathrm{B}$ may be due to the occurrence of the double bond at $\mathrm{C} 5 \mathrm{a}$ in tryptanthrin, as compared to the supplemental ethyl moiety in indigodole B. Thus, the supplementation of a double bond in the quinazoline ring for substances based on structural conformity for tryptanthrin could substantially elevate their antiviral activity. Furthermore, tryptanthrin has also shown a wide range of biological activities, including anti-allergic, antioxidant, anti-inflammatory, anti-protozoal, antimicrobial, and anticancer action (108). Tryptanthrin has also been observed to prevent the early and late replication periods of $\mathrm{HCoV}$ NL63 by inhibiting the post-entry replication stage of $\mathrm{HCoV}$, blocking papain-like protease two activity, and the viral RNA genome synthesis (68). As the spike protein of HCoV-NL63 targets hACE2 receptors such as SARS-CoV and SARS-CoV-2, this indicates a high structural similarity and conserved sequence between these viruses (109). Thus, tryptanthrin has a high latency to be assessed as a potential anti-SARS-CoV-2 agent.

Finally, besides the antiviral potential of griffithsin and silvestrol against MERS-CoV, as mentioned earlier, they also appear to have inhibition impacts against other human coronaviruses. Griffithsin has demonstrated high antiviral impacts $\left(\mathrm{EC}_{50}\right.$ of $\left.0.0032-0.33 \mu \mathrm{M}\right)$ against several $\mathrm{HCoV}$ strains (99), and silvestrol inhibited ( $\mathrm{EC}_{50}$ of $3 \mathrm{nM}$ ) HCoV-229E protein translation (65). A follow-up study attributed the inhibition potential of silvestrol to $\mathrm{HCoV}-229 \mathrm{E}$ in an ex vivo bronchial epithelial cell system to the inhibition of RNA helicase eIF4A (110).

\section{Animal Coronaviruses}

A broad spectrum of livestock and domestic animals suffers from severe morbidity and mortality caused by many strains of animal coronavirus, leading to a sizeable economic demise around the world $(111,112)$. Coronaviruses are considered by their ability to adapt and rapidly mutate in addition to their genomic diversity, and these characteristics represent a unique challenge for the development of new antivirals. Therefore, it is important to explore alternative ways to control these viruses that can be effective across many or all serotypes. Several of the natural plantderived substances have shown high antiviral activity against several animal coronaviruses (Table 3) through one or more of these mechanisms: (1) stimulation of the immune response of the host (123), (2) the direct inhibition of some viral parts such as spike proteins or proteases as abovementioned in the method of antiviral impacts of silvestrol and griffithsin $(65,98)$, and (3) hosttargeting forming antiviral substances, thus blocking the virus entry to the host's cell, for example, inhibition of the clathrinbased endocytosis pathway by extracts of Cinnamomi sp. that avoid the virus entry to the host cells for instance (124). Different strains of corona virus in animals are illustrated in Figure 4.

\section{Porcine Epidemic Diarrhea Virus}

Porcine epidemic diarrhea virus (PEDV) is a severe enteric coronavirus from the $\alpha-\mathrm{CoV}$ subclass that infects the cells lining pigs' gastrointestinal tract causing severe dehydration and diarrhea, leading to economic losses in porcine herds worldwide. Many natural phytochemicals have demonstrated antiviral activities against PEDV, particularly quercetin and griffithsin and their derivatives that have also been considered as antiviral agents against human CoVs $(42,65,98)$. It is worth noting that Zhang et al. (57) reported some chemical derivatives that can inhibit SARS-CoV-2 proteases, and quercetin was shortlisted. Furthermore, quercetin-7-rhamnoside at a low concentration of $0.03 \mu \mathrm{M}$ provided $50 \%$ inhibition of viral activity, lower than that of quercetin about 187 times (97), and its specificity was remarkably high $(S I=7,143)$, which is proposed for future clinical trials as well as animal model experiments against SARS-CoV-2. The authentic mode of actions of quercetin-7-rhamnoside or quercetin against PEDV was not yet determined; however, a previous computer modeling study conducted by Zhang et al. (57) has indicated that silico testing (a computer model to complement and accelerate in vivo and in vitro practices) of these compounds inhibits and binds to the SARS-CoV proteases $3 \mathrm{CL}^{\text {pro }}$ and PL ${ }^{\text {pro }}$. These studies emphasized the significance of considering all potential isomers of a compound to identify the most biologically active chemical species.

In general, several studies have emphasized that naturally existing substances active against animal coronavirus strains (e.g., quercetin, griffithsin) are also active against human coronaviruses. This confirms the possibility of using naturalderived substances with recognized antiviral activity to identify drugs for the treatment of animal coronavirus strains of economic importance, such as PEDV. However, it is of concern to test multiple strains of coronavirus when searching for the antiviral potential of phytochemicals and to determine their precise mechanism of effect to develop effective drugs against SARS-CoV-2.

\section{Coronavirus in Cats}

Feline coronavirus (FCoV) is another coronavirus that belongs to the $\alpha-\mathrm{CoV}$ group that causes a severe cat disease and without actual antiviral medication available yet. A computer screening study was conducted by Theerawatanasirikul et al. (120) for a library of naturally occurring compounds against a mutated form of FCoV called feline infectious peritonitis virus (FIPV). The authors, firstly, virtually in vitro screened the potential binding of tested phytochemicals to FIPV $3 \mathrm{CL}^{\text {pro }}$. Then, they used a protease inhibitor assay against the same enzyme to evaluate the 15 most promising compounds in in vitro trials. Among the tested 
TABLE 3 | Antiviral activities of herbal plants and their derivatives against animal coronaviruses.

\begin{tabular}{|c|c|c|c|c|c|c|}
\hline Plant species & Virus strain & Extract type & Bioactive compounds & $\begin{array}{l}E C_{50} \text { or } I_{50} \\
(\mu \mathrm{g} / \mathrm{mL})\end{array}$ & Mechanism(s) of action & References \\
\hline Ginkgo biloba & PEDV CV 777 & Ethanol extract (98\%) & Polysaccharide mixture & $1.7 \pm 1.3$ & $\begin{array}{l}\text { Inhibits viral attachment and } \\
\text { entry steps in a } \\
\text { dose-dependent manner }\end{array}$ & $(113)$ \\
\hline Griffithsia sp. & PEDV (NJ-PEDV) & $\begin{array}{l}\text { Used purified } \\
\text { compound }\end{array}$ & Griffithsin & $\sim 0.08 \mu \mathrm{M}$ & $\begin{array}{l}\text { Prevents viral attachment to } \\
\text { host cells }\end{array}$ & $(114)$ \\
\hline $\begin{array}{l}\text { Houttuynia } \\
\text { cordata }\end{array}$ & PEDV CV 777 & Methanol extract & $\begin{array}{l}\text { Quercetin } \\
\text { Quercetin 7-rhamnoside } \\
\text { Luteolin } \\
\text { Apigenin } \\
\text { Possibly polyphenols }\end{array}$ & $\begin{array}{l}\sim 5.6 \pm 2.6 \mu \mathrm{M} \\
\sim 0.03 \pm 0.01 \mu \mathrm{M} \\
\sim 0.7 \pm 0.7 \mu \mathrm{M} \\
\sim 0.4 \pm 0.4 \mu \mathrm{M} \\
1.95\end{array}$ & Not determined & $(97)$ \\
\hline $\begin{array}{l}\text { Amelanchier } \\
\text { alnifolia } \\
\text { Rosa nutkana }\end{array}$ & BCV & Methanol extract & $\begin{array}{l}\text { A. alnifolia: possibly } \\
\text { prunasin } \\
\text { R. nutkana: ND }\end{array}$ & $\begin{array}{l}<200 \\
<200\end{array}$ & Not determined & $(115)$ \\
\hline Alstonia scholaris & Avian IBV & Ethanol extract (50\%) & $\begin{array}{l}\text { Alstotide } 1 \\
\text { Alstotide } 3\end{array}$ & $\begin{array}{l}35 \mu \mathrm{M} \\
55 \mu \mathrm{M}\end{array}$ & $\begin{array}{l}\text { Interferes with spike } \\
\text { proteins and membrane }\end{array}$ & $(116)$ \\
\hline $\begin{array}{l}\text { Eucalypts and } \\
\text { several other } \\
\text { plants }\end{array}$ & $\begin{array}{l}\text { Avian IBV Gray } \\
\text { strain }\end{array}$ & $\begin{array}{l}\text { Used chemical } \\
\text { standard }\end{array}$ & Eucalyptol (1,8-cineole) & $0.61 \pm 0.7 \mathrm{mM}$ & $\begin{array}{l}\text { Incompatible with the } \\
\text { association between IBV } \\
\text { nucleocapsid protein and } \\
\text { RNA }\end{array}$ & $(117)$ \\
\hline Sambucus nigra & $\begin{array}{l}\text { Avian IBV } \\
\text { Beaudette strain }\end{array}$ & Ethanol extract (70\%) & Possibly lectins or flavonols & ND & $\begin{array}{l}\text { Compromises membrane } \\
\text { integrity and disrupts virion } \\
\text { structure }\end{array}$ & $(118)$ \\
\hline Galanthus nivalis & FCoV NTU156 & $\begin{array}{l}\text { Used commercial } \\
\text { standard }\end{array}$ & Galanthus nivalis agglutinin & $0.0088 \mathrm{nM}$ & $\begin{array}{l}\text { Binds to membrane proteins } \\
\text { and spike proteins }\end{array}$ & (119) \\
\hline $\begin{array}{l}\text { Lichen and several } \\
\text { other plant species }\end{array}$ & FCoV (FIPV1146) & $\begin{array}{l}\text { Used commercial } \\
\text { standard }\end{array}$ & $\begin{array}{l}\text { Quercetin 7-rhamnoside } \\
\text { 7-Methyl luteolin } \\
\text { Steviol } \\
\text { 7-benzyl luteolin }\end{array}$ & $\begin{array}{l}77.2 \pm 13.8 \\
28.5 \pm 4.2 \\
500 \\
>500\end{array}$ & Inhibition of 3CLpro & $(120)$ \\
\hline $\begin{array}{l}\text { Sophorae sp. } \\
\text { Sanguisorbae sp. } \\
\text { Torilis sp. } \\
\text { Acanthopanacis sp. }\end{array}$ & MHV-A59 & Methanol extract & Not determined & $\begin{array}{l}0.8 \pm 0.2 \\
3.7 \pm 1.4 \\
0.8 \pm 0.0(\mu \mathrm{g} / \mathrm{mL}) \\
0.9 \pm 0.1\end{array}$ & $\begin{array}{l}\text { Inhibition of protease activity } \\
\text { or RNA-dependent RNA } \\
\text { polymerase }\end{array}$ & $(121)$ \\
\hline Punica granatum & MHV-A59 & Ethanol/water extract & Possibly polyphenols & $\geq 200 \mu \mathrm{g} / \mathrm{mL}$ & $\begin{array}{l}\text { Interact with surface } \\
\text { glycoprotein spikes }\end{array}$ & $(114)$ \\
\hline $\begin{array}{l}\text { Nigella sativa } \\
\text { Anthemis hyaline } \\
\text { Citrus sinensis } \\
\text { Ziziphus jujuba }\end{array}$ & MHV-A59 & Ethanol extract & Not determined & ND & Inhibition of viral replication & $(122)$ \\
\hline
\end{tabular}

PEDV, porcine epidemic diarrhea virus; IBV, (avian) infectious bronchitis virus; BCV, bovine coronavirus; FCoV, feline coronavirus; MHV, mouse hepatitis virus; ND, no data.

compounds, no inhibition $\left(\mathrm{IC}_{50}>500 \mu \mathrm{M}\right)$ was observed by steviol and 7-benzyl luteolin; however, moderate inhibition $\left(\mathrm{IC}_{50}\right.$ of 77.2 $\pm 13.8 \mu \mathrm{M}$ ) was demonstrated by quercetin 7-rhamnoside whereas 7-methyl luteolin and stictic acid showed the lowest $\mathrm{IC}_{50}$ values $(28.5 \pm 4.2$ and $29.4 \pm 4.6 \mu \mathrm{M}$, respectively). While, when the authors used the cytopathic effect assay to test these active compounds, only stictic acid showed a protective impact on viralinduced apoptosis. Furthermore, Hsieh et al. (119) considered Galanthus nivalis agglutinin as a potent inhibitor of FCoV, with high selectivity index (>218) and $\mathrm{EC}_{50}$ of just $0.0088 \mathrm{nM}$, through binding to its membrane and spike proteins, and prevented its attachment to the host cells. The authors reported that this mannose-binding lectin outperformed all comparable synthetic antiviral agents.

Another screening study against 19 substances was conducted by McDonagh et al. (125), and the authors focused on naturally occurring compounds that have been observed to have antiviral impacts against coronavirus strains or other RNA virus strains. They used many phytochemicals, including hesperitin, artemisinin, baicalin, glycyrrhizic acid quercetin, hesperidin, curcumin, and rutin at single doses ranging from 10 to $50 \mu \mathrm{M}$. Although none of these agents reached $\mathrm{EC}_{50}$, glycyrrhizic acid at a level of $25 \mu \mathrm{M}$ was the most promising, causing a decrease in cytopathic influence assay by $26.7 \%$. Despite these findings, further researchers are required to examine more concentrations of these compounds against FCoV.

\section{Murine Coronavirus}

Several medicinal herbal extracts were examined in vitro against coronaviruses in mice (strain MHV-A59) but without determining the particular substances responsible for virus inhibition $(121,126)$. However, based on the abundance in the 


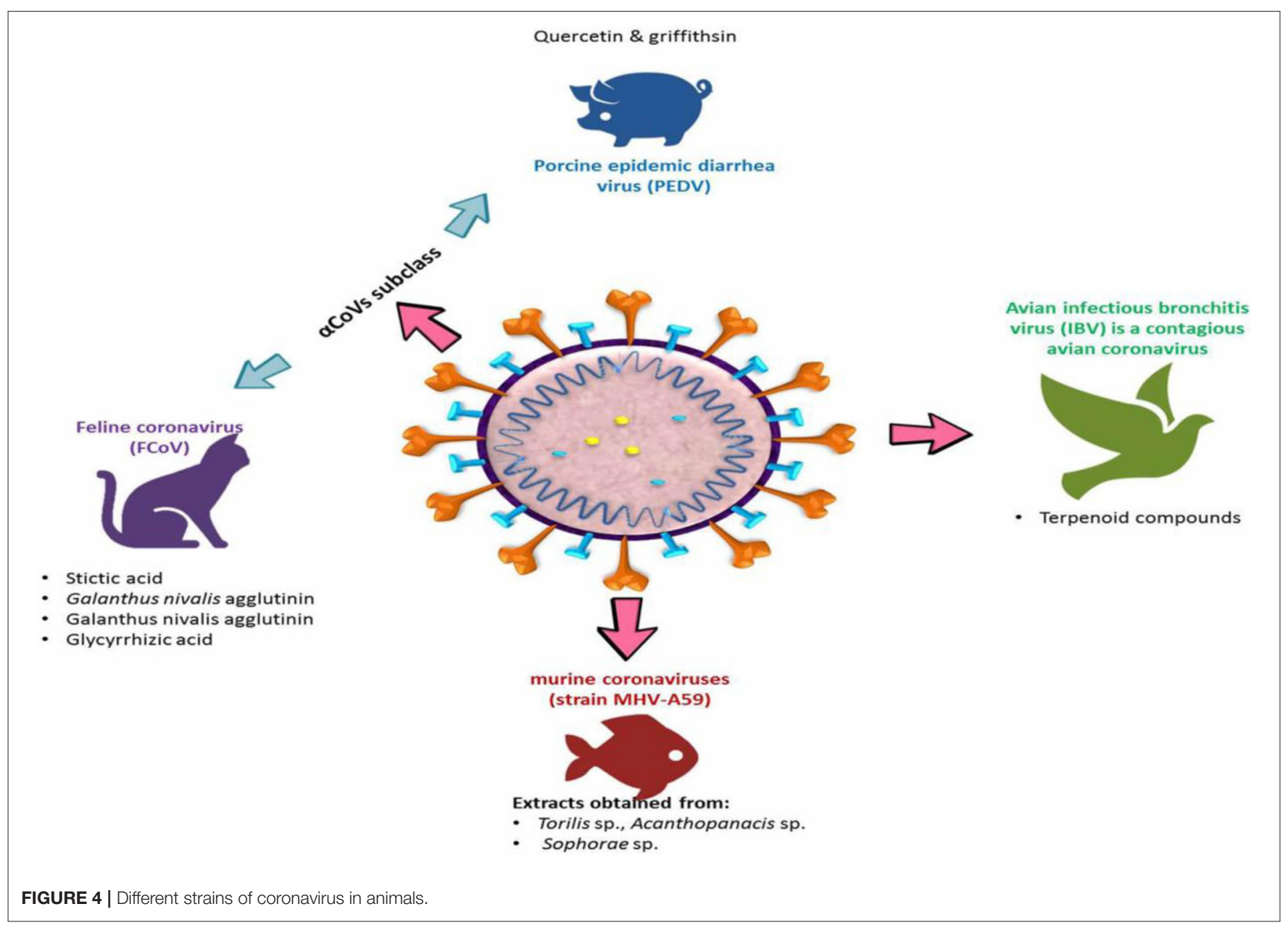

tested extracts, the authors proposed potential compounds or classes of compounds that may be responsible for this impact. The significant inhibitory potential was observed to the extracts acquired from Torilis sp., Acanthopanacis sp., and Sophorae sp. when tested at low concentrations $(<1 \mu \mathrm{g} / \mathrm{mL})$. Specifically, the extract of the Sophorae sp. root exhibited high viral specificity $(S I=696)$, suggesting that it could be powerfully selected for future investigations aiming to screen and identify compounds that have antiviral potential. The authors suggested that the inhibition of the activity of proteases, such as RNA-dependent RNA polymerase, might be the potential mechanism of these three species to exert their antiviral activities (Table 3 ).

\section{Avian Coronavirus}

Avian infectious bronchitis virus (IBV) is a contagious avian coronavirus that influences the respiratory tract, reproductive systems, gastrointestinal tract, and kidney of chickens, causing avian infectious bronchitis disease. Several studies have tested the antiviral potential of plant-derived extracts against IBV (112, $116,127)$. The main mechanisms of action of viral inhibition that have been recognized in all studies on IBV appear to be through interference with the spike protein or viral envelope disruption. However, terpenoid compounds (-)- $\beta$-pinene, (-)- $\alpha$-pinene, and 1,8-cineole have an exceptional mechanism to inhibit IBV and breaking its replication cycle via binding to $\mathrm{N}$ protein of the virus, thereby preventing its interference with the viral genomic RNA $(117,128)$. The structural models of the terpenoids supported the previous observations as it showed that these substances can actively connect to five amino acid residues at the active site at the $\mathrm{N}$ terminus of the $\mathrm{N}$ protein (TyrA140, TyrA92, As A138, PheA137, and ProA134) (117, 128). Yang et al. (117) reported that these amino acid residues are considerably preserved among avian coronavirus strains. Therefore, terpenoids/isoprenoids, organic chemicals derived from terpenes, can be considered as potentially strong antiviral agents against almost all IBV strains and as a reasonable target for further investigations.

The coronavirus envelope protein (E protein) is another main key target for many investigators. The E protein of avian IBV is integral to the life cycle of the virus at different stages, so any disruption or inhibition of it may lead to the elimination of these viruses.

Phytochemicals and medicinal herbal extracts may be useful in this role. Chen et al. (118) noticed that treatment with S. nigra extract inactivated two eminent enveloped viruses (influenza and avian IBV). The authors suggested that the extract of S. nigra may have the possibility to exhibit antiviral impacts 
against a broad spectrum of other enveloped viruses, which can be attributed to the potential synergistic effect among the extract's inhibitory compounds, particularly flavonoids and lectins. Enhancing innate immunity against SARS-CoV-2 is essential in the absence of efficacious drugs and/or vaccine treatments. In this regard, animal experiments may be a useful model to test the effectiveness of medicinal, herbs, and spice products as antiviral agents.

\section{Past Experiences, Current Situations, and Future Strategy}

The current review presents an overview of the present knowledge and existing advances related to herbal plants and natural phytochemicals as potential agents against SARS-CoV2 and COVID-19. Although several drugs, vitamins, minerals, and immune-stimulators are in full use to reduce the mortalities and provide appropriate medical care for the infected persons, the search for active and specific therapeutic agents is required as soon as possible. Furthermore, several agencies, companies, and research institutes, as well as different health organizations and $\mathrm{WHO}$, are on the way to find and develop a vaccine against COVID-19. Currently, with the appearance of the COVID-19 pandemic, continuous investigations have been tried by scientists to find active compounds from natural sources such as plants that could inhibit and/or stop the virus replication. However, the strategy of control, prevention, and eradication of the infection of COVID-19 needs collaboration to effectively apply social distancing and precautions to reduce or stop the further spread of COVID-19. Control of the COVID-19 outbreak and future epidemics requires global efforts among clinicians, immunologists, nutritionists, researchers, veterinarians, pharmacists. Also, public awareness should be focused on the role of nutrition, medicines, spices, herbs, and natural phytochemicals, enhancing the immune system and thus health. In addition, recent published trials by Ulasli et al. (122) and $\mathrm{Oh}$ et al. (129) indicated that a promising role

\section{REFERENCES}

1. Wu A, Peng Y, Huang B, Ding X, Wang X, Niu P, et al. Genome composition and divergence of the novel coronavirus (2019-nCoV) originating in China. Cell Host Microbe. (2020):325-8. doi: 10.1016/j.chom.2020. 02.001

2. Chu DK, Pan Y, Cheng SM, Hui KP, Krishnan P, Liu Y, et al. Molecular diagnosis of a novel coronavirus (2019-nCoV) causing an outbreak of pneumonia. Clin Chem. 2020) 66:549-55. doi: 10.1093/clinchem/hvaa029

3. Lu G, Wang Q, Gao GF. Bat-to-human: spike features determining 'host jump' of coronaviruses SARS-CoV, MERS-CoV, and beyond. Trends Microbiol. (2015) 23:468-78. doi: 10.1016/j.tim.2015.06.003

4. Yang $\mathrm{Y}$, Peng $\mathrm{F}$, Wang $\mathrm{R}$, Guan $\mathrm{K}$, Jiang $\mathrm{T}$, Xu G, et al. The deadly coronaviruses: the 2003 SARS pandemic and the 2020 novel coronavirus epidemic in China. J Autoimmun. (2020) 109:102434. doi: 10.1016/j.jaut.2020.102434

5. Paraskevis D, Kostaki EG, Magiorkinis G, Panayiotakopoulos G, Sourvinos G, Tsiodras S. Full-genome evolutionary analysis of the novel coronavirus (2019-nCoV) rejects the hypothesis of emergence as a result of a recent recombination event. Infect Genet Evo. (2020) 79:104212. doi: 10.1016/j.meegid.2020.104212 of herbs and spices in enhancing immunity incorporation of spices into daily diet may help reduce postprandial inflammation and concurrently attenuate chronic low-grade inflammation in vitro. In addition, in a clinical trial, El Sayed et al. (130) found that honey, Nigella sativa, and clove could cure people with COVID-19. Nonetheless, research is needed to identify the candidates' agents and examine their effectiveness through clinical experiments $(131,132)$.

\section{CONCLUSIONS}

Medicinal herbal plants and natural phytochemicals represent a powerful and valuable resource of active compounds that exhibit antiviral activities. Some of these sources require further chemical modification to enhance their potency and selectivity. Finding effective treatments for human and animal coronaviruses can benefit from testing several compounds and polyphenolics such as caffeic acid, isobavachalcone, myricetin, psoralidin, and quercetin, griffithsin, lycorine, silvestrol, and tryptanthrin. These compounds must be examined in in vitro and in vivo experiments to ensure their therapeutic and safe levels before conducting human clinical trials because of their toxicity at specific doses. The prime candidates for initial studies are these compounds that have been recognized by the FDA or other national or international organizations as generally safe or that have previously been allowed for medicinal uses. This review provides essential information on the potential role of phytochemicals in inhibiting coronavirus strains. This may provide adequate evidence to researchers seeking active therapeutic agents against SARS-CoV-2. Thus, naturally derived compounds alone or in integration with western medications may be further tested.

\section{AUTHOR CONTRIBUTIONS}

All authors listed have made a substantial, direct and intellectual contribution to the work, and approved it for publication.
6. World Health Organization. WHO MERS Global Summary and Assessment of Risk. Geneva: World Health Organization (2019).

7. Sohrabi C, Alsafi Z, O’Neill N, Khan M, Kerwan A, Al-Jabir A, et al. World Health Organization declares global emergency: a review of the 2019 novel coronavirus (COVID-19). Int J Surg. (2020) 76:71-6. doi: 10.1016/j.ijsu.2020.02.034

8. Hui D, I Azhar E, Madani T, Ntoumi F, Koch R, Dar O, et al. The continuing 2019-nCoV epidemic threat of novel coronaviruses to global health: the latest 2019 novel coronavirus outbreak in Wuhan, China. Int J Infect Dis. (2020) 91:264-6. doi: 10.1016/j.ijid.2020.01.009

9. Wu C, Liu Y, Yang Y, Zhang P, Zhong W, Wang Y, et al. Analysis of therapeutic targets for SARS-CoV-2 and discovery of potential drugs by computational methods. Acta Pharmaceut Sin B. (2020) 10:766-88. doi: 10.1016/j.apsb.2020.02.008

10. Gao J, Tian Z, Yang X. Breakthrough: chloroquine phosphate has shown apparent efficacy in treatment of COVID-19 associated pneumonia in clinical studies. Biosci Trends. (2020) 14:72-3. doi: 10.5582/bst.2020.01047

11. Cortegiani A, Ingoglia G, Ippolito M, Giarratano A, Einav S. A systematic review on the efficacy and safety of chloroquine for the treatment of COVID-19. J Crit Care. (2020) 57:279-83. doi: 10.1016/j.jcrc.2020. 03.005 
12. Holshue ML, DeBolt C, Lindquist S, Lofy KH, Wiesman J, Bruce H, et al. First case of 2019 novel coronavirus in the United States. New Engl J Med. (2020) 382:929-36. doi: 10.1056/NEJMoa2001191

13. Khamitov R, Loginova S, Shchukina V, Borisevich S, Maksimov V, Shuster A. Antiviral activity of arbidol and its derivatives against the pathogen of severe acute respiratory syndrome in the cell cultures. Vopr Virusol. (2008) 53:9-13.

14. Lu H. Drug treatment options for the 2019-new coronavirus (2019-nCoV). Biosci Trends. (2020) 14:69-71. doi: 10.5582/bst.2020.01020

15. Wang $\mathrm{M}$, Cao R, Zhang L, Yang X, Liu J, Xu M, et al. Remdesivir and chloroquine effectively inhibit the recently emerged novel coronavirus (2019-nCoV) in vitro. Cell Res. (2020) 30:269-71. doi: 10.1038/s41422-020-0282-0

16. Yao TT, Qian JD, Zhu WY, Wang Y, Wang GQ. A systematic review of lopinavir therapy for SARS coronavirus and MERS coronavirus-a possible reference for coronavirus disease-19 treatment option. J Med Virol. (2020) 92:556-63. doi: 10.1002/jmv.25729

17. Estevam EC, Griffin S, Nasim MJ, Zieliński D, Aszyk J, Osowicka M, et al. Inspired by nature: the use of plant-derived substrate/enzyme combinations to generate antimicrobial activity in situ. Nat Prod Commun. (2015) 10:17338. doi: $10.1177 / 1934578 \mathrm{X} 1501001025$

18. Attia YA, Al-Harthi MA. Nigella seed oil as an alternative to antibiotic growth promoters for broiler chickens. Europ Poult Sci. (2015) 79:1-13. doi: $10.1399 /$ eps.2015.80

19. Abd El-Hack ME, Alagawany M, Abdel-Moneim A-ME, Mohammed NG, Khafaga AF, Bin-Jumah M, et al. Cinnamon (Cinnamomum zeylanicum) oil as a potential alternative to antibiotics in poultry. Antibiotics. (2020) 9:210-21. doi: 10.3390/antibiotics9050210

20. Sardi J, Scorzoni L, Bernardi T, Fusco-Almeida A, Giannini MM. Candida species: current epidemiology, pathogenicity, biofilm formation, natural antifungal products and new therapeutic options. J Med Microbiol. (2013) 62:10-24. doi: 10.1099/jmm.0.045054-0

21. Nuraskin C, Idroes R, Soraya C. Activities inhibition methanol extract Laban Leaf (Vitex pinnata) on growth of bacteria S. mutans Atcc 31987. In: IOP Conference Series: Materials Science and Engineering. Vol. 1. Banda Aceh: IOP Publishing (2019). p. 012008. doi: 10.1088/1757-899X/523/1/012008

22. Pratiwi S, Lagendijk E, de Weert S, Idroes R, Hertiani T, Van den Hondel C. Effect of Cinnamomum burmannii Nees ex Bl. and Massoia aromatica Becc. Essential oils on planktonic growth and biofilm formation of Pseudomonas aeruginosa and Staphylococcus aureus In Vitro. Int J Appl Res Nat Prod. (2015) 8:1-13. doi: 10.1055/s-0036-1596813

23. Rahmad R, Earlia N, Nabila C, Inayati I, Amin M, Prakoeswa C, et al. Antibacterial cream formulation of ethanolic Pliek U extracts and ethanolic residue hexane Pliek U extracts against Staphylococcus aureus. In: IOP Conference Series: Materials Science and Engineering. Vol. 1. Banda Aceh: IOP Publishing (2019). p. 012011. doi: 10.1088/1757-899X/523/1/ 012011

24. Calland N, Dubuisson J, Rouillé Y, Séron K. Hepatitis C virus and natural compounds: a new antiviral approach? Viruses. (2012) 4:2197-217. doi: $10.3390 / \mathrm{v} 4102197$

25. Hu Q-F, Zhou B, Huang J-M, Gao X-M, Shu L-D, Yang G-Y, et al. Antiviral phenolic compounds from Arundina gramnifolia. J Nat Prod. (2013) 76:2926. doi: $10.1021 / \mathrm{np} 300727 \mathrm{f}$

26. Earlia N, Suhendra R, Amin M, Prakoeswa C, Idroes R. GC/MS analysis of fatty acids on pliek u oil and its pharmacological study by molecular docking to filaggrin as a drug candidate in atopic dermatitis treatment. Sci World J. (2019) 2019:8605743. doi: 10.1155/2019/8605743

27. Earlia N, Rahmad R, Amin M, Prakoeswa C, Khairan K, Idroes R. The potential effect of fatty acids from pliek $\mathrm{U}$ on epidermal fatty acid binding protein: chromatography and bioinformatic studies. Sains Malays. (2019) 48:1019-24. doi: 10.17576/jsm-2019-4805-10

28. Khaerunnisa S, Kurniawan H, Awaluddin R, Suhartati S, Soetjipto S. Potential inhibitor of COVID-19 main protease (Mpro) from several medicinal plant compounds by molecular docking study. Preprints. (2020) 0226:1-14. doi: 10.20944/preprints202003.0226.v1

29. Shaghaghi N. Molecular docking study of novel COVID-19 protease with low risk terpenoides compounds of plants. ChemRxiv Preprint. (2020). doi: $10.26434 /$ chemrxiv.11935722
30. ul Qamar MT, Alqahtani SM, Alamri MA, Chen L-L. Structural basis of SARS-CoV-2 3CLpro and anti-COVID-19 drug discovery from medicinal plants. J Pharm Anal. (2020) 10:313-9. doi: 10.1016/j.jpha.2020.03.009

31. Xu X, Han M, Li T, Sun W, Wang D, Fu B, et al. Effective treatment of severe COVID-19 patients with tocilizumab. Proc Natl Acad Sci USA. (2020) 117:10970-5. doi: 10.1073/pnas.2005615117

32. Ma Q, Yu Q, Xing X, Liu S, Shi C, Luo J. San wu huangqin decoction, a chinese herbal formula, inhibits influenza a/PR/8/34 (H1N1) virus infection in vitro and in vivo. Viruses. (2018) 10:117. doi: 10.3390/v10030117

33. Ding Y, Zeng L, Li R, Chen Q, Zhou B, Chen Q, et al. The Chinese prescription lianhuaqingwen capsule exerts anti-influenza activity through the inhibition of viral propagation and impacts immune function. $B M C$ Complement Altern Med. (2017) 17:130. doi: 10.1186/s12906-017-1585-7

34. Du H-X, Zhou H-F, Wan H-F, Yang J-H, Lu Y-Y, He Y, et al. Antiviral effects and mechanisms of Yinhuapinggan granule against H1N1 influenza virus infection in RAW264. 7 cells. Inflammopharmacology. (2018) 26:1455-67. doi: 10.1007/s10787-018-0457-1

35. Liu D, Liang B, Huang L. Clinical observation on the preventive effect of kangdu bufei decoction on acute severe respiratory syndrome. Zhongguo Zhong Xi Yi Jie He Za Zhi. (2004) 24:685-8.

36. Tong X, Li A, Zhang Z, Duan J, Chen X, Hua C, et al. TCM treatment of infectious atypical pneumonia-a report of 16 cases. J Tradit Chin Med. (2004) 24:266-9.

37. Liu B, He L, Liang Z, Tong X, Hu J, Jiao Q, et al. Effect of glucocorticoid with traditional Chinese medicine in severe acute aespiratory syndrome (SARS). Zhongguo Zhong Yao Za Zhi. (2005) 30:1874-7.

38. Hai X. Clinical experience of SARS treatment in Guangdong province. Tianjin J Trad Chinese. (2003) 20:24-5.

39. Jia J. Traditional Chinese medicine integrated western medicine for SARS. Tianjin J Trad Chinese Med. (2003) 20:28-30.

40. Li Y, Liu X, Guo L, Li J, Zhong D, Zhang Y, et al. Traditional Chinese herbal medicine for treating novel coronavirus (COVID-19) pneumonia: protocol for a systematic review and meta-analysis. Syst Rev. (2020) 9:1-6. doi: 10.1186/s13643-020-01343-4

41. Abd El-Hack ME, Abdelnour SA, Abd El-Moneim AE, Arif M, Khafaga A, Shaheen $\mathrm{H}$, et al. Putative impacts of phytogenic additives to ameliorate lead toxicity in animal feed. Environ Sci Pollut Res. (2019) 26:23209-18. doi: 10.1007/s11356-019-05805-8

42. Tallei TE, Tumilaar SG, Niode NJ, Fatimawali F, Kepel BJ, Idroes R, e al. Potential of plant bioactive compounds as SARS-CoV-2 main protease (Mpro) and spike (S) glycoprotein inhibitors: a molecular docking study. Preprintsorg. (2020) 1-18. doi: 10.20944/preprints202004.0102.v3

43. Lipinski CA. Lead-and drug-like compounds: the rule-offive revolution. Drug Discov Today Technol. (2004) 1:337-41. doi: 10.1016/j.ddtec.2004.11.007

44. Benet LZ, Hosey CM, Ursu O, Oprea TI. BDDCS, the rule of 5 and drugability. Adv Drug Deliv Rev. (2016) 101:89-98. doi: 10.1016/j.addr.2016.05.007

45. Liu X, Wang X-J. Potential inhibitors against 2019-nCoV coronavirus $\mathrm{M}$ protease from clinically approved medicines. J Genet Genom. (2020) 47:11921. doi: 10.1016/j.jgg.2020.02.001

46. Song W, Gui M, Wang X, Xiang Y. Cryo-EM structure of the SARS coronavirus spike glycoprotein in complex with its host cell receptor ACE2. PLoS Pathog. (2018) 14:e1007236. doi: 10.1371/journal.ppat.1007236

47. Coutard B, Valle C, de Lamballerie X, Canard B, Seidah N, Decroly E. The spike glycoprotein of the new coronavirus $2019-\mathrm{nCoV}$ contains a furinlike cleavage site absent in $\mathrm{CoV}$ of the same clade. Antiviral Res. (2020) 176:104742. doi: 10.1016/j.antiviral.2020.104742

48. Lin L, Wong H. Predicting oral drug absorption: mini review on physiologically-based pharmacokinetic models. Pharmaceutics. (2017) 9:41. doi: 10.3390/pharmaceutics9040041

49. Adem S, Eyupoglu V, Sarfraz I, Rasul A, Ali M. Identification of potent COVID-19 main protease (Mpro) inhibitors from natural polyphenols: an in silico strategy unveils a hope against CORONA. Preprints. (2020) 2020030333. doi: 10.20944/preprints202003.0333.v1

50. Utomo RY, Meiyanto E. Revealing the potency of citrus and galangal constituents to halt SARS-CoV-2 infection. PreprintsOrg. (2020) 1-8. doi: 10.20944/preprints202003.0214.v1 
51. Chen YW, Yiu C-PB, Wong K-Y. Prediction of the SARS-CoV-2 (2019-nCoV) 3C-like protease (3CL pro) structure: virtual screening reveals velpatasvir, ledipasvir, and other drug repurposing candidates. F1000Research. (2020) 9:129. doi: 10.12688/f1000research.22457.1

52. Reiss CS. Cannabinoids and viral infections. Pharmaceuticals. (2010) 3:187386. doi: 10.3390/ph3061873

53. Blevins RD, Dumic MP. The effect of $\Delta$-9-tetrahydrocannabinol on herpes simplex virus replication. J Gen Virol. (1980) 49:427-31. doi: 10.1099/0022-1317-49-2-427

54. Abd El-Hack ME, Elnesr SS, Alagawany M, Gado A, Noreldin AE, Gabr AA. Impact of green tea (Camellia sinensis) and epigallocatechin gallate on poultry. World's Poultry Sci J. (2020) 76:49-63. doi: 10.1080/00439339.2020.1729672

55. Nguyen TTH, Woo H-J, Kang H-K, Kim Y-M, Kim D-W, Ahn SA, et al. Flavonoid-mediated inhibition of SARS coronavirus 3C-like protease expressed in Pichia pastoris. Biotechnol Lett. (2012) 34:831-8. doi: 10.1007/s10529-011-0845-8

56. Ahmed M, Henson DA, Sanderson MC, Nieman DC, Zubeldia JM, Shanely RA. Rhodiola rosea exerts antiviral activity in athletes following a competitive marathon race. Front Nutr. (2015) 2:24. doi: $10.3389 /$ fnut.2015.00024

57. Zhang D-H, Wu K-L, Zhang X, Deng S-Q, Peng B. In silico screening of Chinese herbal medicines with the potential to directly inhibit 2019 novel coronavirus. J Integr Med. (2020) 18:152-8. doi: 10.1016/j.joim.2020.02.005

58. Lung J, Lin YS, Yang YH, Chou YL, Shu LH, Cheng YC, et al. The potential chemical structure of anti-SARS-CoV-2 RNA-dependent RNA polymerase. $J$ Med Virol. (2020) 92:693-7. doi: 10.1002/jmv.25761

59. Li S-Y, Chen C, Zhang H-Q, Guo H-Y, Wang H, Wang L, et al. Identification of natural compounds with antiviral activities against SARS-associated coronavirus. Antiviral Res. (2005) 67:18-23. doi: 10.1016/j.antiviral.2005.02.007

60. Chen C-J, Michaelis M, Hsu H-K, Tsai C-C, Yang KD, Wu Y-C, et al. Toona sinensis Roem tender leaf extract inhibits SARS coronavirus replication. $J$ Ethnopharmacol. (2008) 120:108-11. doi: 10.1016/j.jep.2008.07.048

61. Hoever G, Baltina L, Michaelis M, Kondratenko R, Baltina L, Tolstikov GA, et al. Antiviral activity of glycyrrhizic acid derivatives against SARScoronavirus. J Med Chem. (2005) 48:1256-9. doi: 10.1021/jm0493008

62. Wen C-C, Shyur L-F, Jan J-T, Liang P-H, Kuo C-J, Arulselvan P, et al. Traditional Chinese medicine herbal extracts of Cibotium barometz, Gentiana scabra, Dioscorea batatas, Cassia tora, and Taxillus chinensis inhibit SARS-CoV replication. J Trad Complement Med. (2011) 1:41-50. doi: 10.1016/S2225-4110(16)30055-4

63. Kumaki Y, Wandersee MK, Smith AJ, Zhou Y, Simmons G, Nelson $\mathrm{NM}$, et al. Inhibition of severe acute respiratory syndrome coronavirus replication in a lethal SARS-CoV $\mathrm{BALB} / \mathrm{c}$ mouse model by stinging nettle lectin, Urtica dioica agglutinin. Antiv Res. (2011) 90:22-32. doi: 10.1016/j.antiviral.2011.02.003

64. Wang S-Q, Du Q-S, Zhao K, Li A-X, Wei D-Q, Chou K-C. Virtual screening for finding natural inhibitor against cathepsin-L for SARS therapy. Amino Acids. (2007) 33:129-35. doi: 10.1007/s00726-006-0403-1

65. Müller C, Schulte FW, Lange-Grünweller K, Obermann W, Madhugiri R, Pleschka S, et al. Broad-spectrum antiviral activity of the eIF4A inhibitor silvestrol against corona-and picornaviruses. Antiviral Res. (2018) 150:123-9. doi: 10.1016/j.antiviral.2017.12.010

66. Park J-Y, Yuk HJ, Ryu HW, Lim SH, Kim KS, Park KH, et al. Evaluation of polyphenols from Broussonetia papyrifera as coronavirus protease inhibitors. J Enzyme Inhib Med Chem. (2017) 32:504-12. doi: 10.1080/14756366.2016.1265519

67. Kim DE, Min JS, Jang MS, Lee JY, Shin YS, Park CM, et al. Natural bisbenzylisoquinoline alkaloids-tetrandrine, fangchinoline, and cepharanthine, inhibit human coronavirus OC43 infection of MRC-5 human lung cells. Biomolecules. (2019) 9:696. doi: 10.3390/biom9110696

68. Tsai Y-C, Lee C-L, Yen H-R, Chang Y-S, Lin Y-P, Huang S-H, et al. Antiviral action of tryptanthrin isolated from Strobilanthes cusia leaf against human coronavirus NL63. Biomolecules. (2020) 10:366. doi: 10.3390/biom10030366

69. Jo S, Kim H, Kim S, Shin DH, Kim MS. Characteristics of flavonoids as potent MERS-CoV 3C-like protease inhibitors. Chem Biol Drug Design. (2019) 94:2023-30. doi: 10.1111/cbdd.13604
70. Jo S, Kim S, Shin DH, Kim M-S. Inhibition of SARS-CoV 3CL protease by flavonoids. J Enzyme Inhib Med Chem. (2020) 35:145-51. doi: 10.1080/14756366.2019.1690480

71. Forli S, Huey R, Pique ME, Sanner MF, Goodsell DS, Olson AJ. Computational protein-ligand docking and virtual drug screening with the AutoDock suite. Nat Protoc. (2016) 11:905. doi: 10.1038/nprot. 2016.051

72. Aldeghi M, Heifetz A, Bodkin MJ, Knapp S, Biggin PC. Accurate calculation of the absolute free energy of binding for drug molecules. Chem Sci. (2016) 7:207-18. doi: 10.1039/C5SC02678D

73. Mani JS, Johnson JB, Steel JC, Broszczak DA, Neilsen PM, Walsh $\mathrm{KB}$, et al. Natural product-derived phytochemicals as potential agents against coronaviruses: a review. Virus Research. (2020) 284:197989. doi: 10.1016/j.virusres.2020.197989

74. Chen Y, de Bruyn Kops C, Kirchmair J. Data resources for the computerguided discovery of bioactive natural products. J Chem Inf Model. (2017) 57:2099-111. doi: 10.1021/acs.jcim.7b00341

75. Tome-Carneiro J, Visioli F. Polyphenol-based nutraceuticals for the prevention and treatment of cardiovascular disease: review of human evidence. Phytomedicine. (2016) 23:1145-74. doi: 10.1016/j.phymed.2015.10.018

76. Khan H, Sureda A, Belwal T, Çetinkaya S, Süntar I, Tejada S, et al. Polyphenols in the treatment of autoimmune diseases. Autoimmun Rev. (2019) 18:647-57. doi: 10.1016/j.autrev.2019.05.001

77. Runfeng L, Yunlong $\mathrm{H}$, Jicheng $\mathrm{H}$, Weiqi P, Qinhai $\mathrm{M}$, Yongxia S, et al. Lianhuaqingwen exerts anti-viral and anti-inflammatory activity against novel coronavirus (SARS-CoV-2). Pharmacol Res. (2020) 156:104761. doi: 10.1016/j.phrs.2020.104761

78. Toney JH, Navas-Martín S, Weiss SR, Koeller A. Sabadinine: a potential non-peptide anti-severe acute-respiratory-syndrome agent identified using structure-aided design. J Med Chem. (2004) 47:1079-80. doi: $10.1021 / \mathrm{jm} 034137 \mathrm{~m}$

79. Liu B, Zhou J. SARS-CoV protease inhibitors design using virtual screening method from natural products libraries. J Comput Chem. (2005) 26:484-90. doi: $10.1002 /$ jcc. 20186

80. Wang Z-M, Zhu X-X, Cui X-L, Liang A-H, Du G-H, Ruan J-X, et al Screening of traditional Chinese remedies for SARS treatment. Zhongguo Zhong Yao Za Zhi. (2003) 28:484-7.

81. Kretzing S, Abraham G, Seiwert B, Ungemach FR, Krügel U, Regenthal R. Dose-dependent emetic effects of the Amaryllidaceous alkaloid lycorine in beagle dogs. Toxicon. (2011) 57:117-24. doi: 10.1016/j.toxicon.2010. 10.012

82. Yu M-S, Lee J, Lee JM, Kim Y, Chin Y-W, Jee J-G, et al. Identification of myricetin and scutellarein as novel chemical inhibitors of the SARS coronavirus helicase, nsP13. Bioorg Med Chem Lett. (2012) 22:4049-54. doi: 10.1016/j.bmcl.2012.04.081

83. Zhao Q, Chen X-Y, Martin C. Scutellaria baicalensis, the golden herb from the garden of Chinese medicinal plants. Sci Bull. (2016) 61:1391-8. doi: 10.1007/s11434-016-1136-5

84. Miean KH, Mohamed S. Flavonoid (myricetin, quercetin, kaempferol, luteolin, and apigenin) content of edible tropical plants. J Agric Food Chem. (2001) 49:3106-12. doi: 10.1021/jf000892m

85. Häkkinen SH, Kärenlampi SO, Heinonen IM, Mykkänen HM, Törrönen AR. Content of the flavonols quercetin, myricetin, and kaempferol in 25 edible berries. J Agric Food Chem. (1999) 47:2274-9. doi: 10.1021/jf9811065

86. Justesen U, Knuthsen P. Composition of flavonoids in fresh herbs and calculation of flavonoid intake by use of herbs in traditional Danish dishes. Food Chem. (2001) 73:245-50. doi: 10.1016/S0308-8146(01)00114-5

87. Kaack K, Austed T. Interaction of vitamin C and flavonoids in elderberry (Sambucus nigra L.) during juice processing. Plant Foods Hum Nutr. (1998) 52:187-98. doi: 10.1023/A:1008069422202

88. Kumar P, Khanna M, Srivastava V, Tyagi YK, Raj HG, Ravi K. Effect of quercetin supplementation on lung antioxidants after experimental influenza virus infection. Exp Lung Res. (2005) 31:449-59. doi: 10.1080/019021490927088

89. Mitchell CA, Ramessar K, O'Keefe BR. Antiviral lectins: selective inhibitors of viral entry. Antiv Res. (2017) 142:37-54 doi: 10.1016/j.antiviral.2017.03.007 
90. Michelow IC, Lear C, Scully C, Prugar LI, Longley CB, Yantosca LM, et al. High-dose mannose-binding lectin therapy for Ebola virus infection. J Infect Dis. (2011) 203:175-9. doi: 10.1093/infdis/jiq025

91. Covés-Datson EM, Dyall J, DeWald LE, King SR, Dube D, Legendre M, et al. Inhibition of Ebola virus by a molecularly engineered banana lectin. PLoS Negl Trop Dis. (2019) 13:e0007595. doi: 10.1371/journal.pntd.0007595

92. Hwang H-J, Han J-W, Jeon H, Cho K, Kim J-H, Lee D-S, et al. Characterization of a novel mannose-binding lectin with antiviral activities from red alga, Grateloupia chiangii. Biomolecules. (2020) 10:333. doi: 10.3390/biom10020333

93. Petersen KA, Matthiesen F, Agger T, Kongerslev L, Thiel S, Cornelissen $\mathrm{K}$, et al. Phase I safety, tolerability, and pharmacokinetic study of recombinant human mannan-binding lectin. J Clin Immunol. (2006) 26:46575. doi: 10.1007/s10875-006-9037-z

94. Keyaerts E, Vijgen L, Pannecouque C, Van Damme E, Peumans W, Egberink $\mathrm{H}$, et al. Plant lectins are potent inhibitors of coronaviruses by interfering with two targets in the viral replication cycle. Antiv Res. (2007) 75:179-87. doi: 10.1016/j.antiviral.2007.03.003

95. Haiying $\mathrm{L}, \mathrm{Na} \mathrm{H}$, Xiaoyuan X. The curative effects of glycyrrhizin on patients with SARS. In: Annual Meeting of The Society of Infectious and Parasitic Diseases, Chinese Medical Association. Wuhan (2003). p. 18-22.

96. Cho JK, Curtis-Long MJ, Lee KH, Kim DW, Ryu HW, Yuk HJ, et al. Geranylated flavonoids displaying SARS-CoV papain-like protease inhibition from the fruits of Paulownia tomentosa. Bioorg Med Chem. (2013) 21:3051-57. doi: 10.1016/j.bmc.2013.03.027

97. Choi H-J, Kim J-H, Lee C-H, Ahn Y-J, Song J-H, Baek S-H, et al. Antiviral activity of quercetin 7-rhamnoside against porcine epidemic diarrhea virus. Antiviral Res. (2009) 81:77-81. doi: 10.1016/j.antiviral.2008.10.002

98. O'Keefe BR, Giomarelli B, Barnard DL, Shenoy SR, Chan PK, McMahon JB, et al. Broad-spectrum in vitro activity and in vivo efficacy of the antiviral protein griffithsin against emerging viruses of the family Coronaviridae. $J$ Virol. (2010) 84:2511-21. doi: 10.1128/JVI.02322-09

99. Millet JK, Séron K, Labitt RN, Danneels A, Palmer KE, Whittaker GR, et al. Middle East respiratory syndrome coronavirus infection is inhibited by griffithsin. Antiv Res. (2016) 133:1-8. doi: 10.1016/j.antiviral.2016.07.011

100. Ushio $\mathrm{Y}, \mathrm{Abe} \mathrm{H}$. Inactivation of measles virus and herpes simplex virus by saikosaponin d. Planta Med. (1992) 58:171-3. doi: 10.1055/s-2006-961422

101. Chiang L-C, Ng LT, Liu L-T, Shieh D-E, Lin C-C. Cytotoxicity and antihepatitis B virus activities of saikosaponins from Bupleurum species. Planta Med. (2003) 69:705-9. doi: 10.1055/s-2003-42797

102. Lin L-T, Chung C-Y, Hsu W-C, Chang S-P, Hung T-C, Shields $\mathrm{J}$, et al. Saikosaponin b2 is a naturally occurring terpenoid that efficiently inhibits hepatitis C virus entry. J Hepatol. (2015) 62:541-8. doi: 10.1016/j.jhep.2014.10.040

103. Cheng PW, Ng LT, Chiang LC, Lin CC. Antiviral effects of saikosaponins on human coronavirus 229E in vitro. Clin Exp Pharmacol Physiol. (2006) 33:612-6. doi: 10.1111/j.1440-1681.2006.04415.x

104. Zhao Y, Feng L, Liu L, Zhao R. Saikosaponin b2 enhances the hepatotargeting effect of anticancer drugs through inhibition of multidrug resistance-associated drug transporters. Life Sci. (2019) 231:116557. doi: 10.1016/j.lfs.2019.116557

105. Weng J-R, Lin C-S, Lai H-C, Lin Y-P, Wang C-Y, Tsai Y-C, et al. Antiviral activity of Sambucus FormosanaNakai ethanol extract and related phenolic acid constituents against human coronavirus NL63. Virus Res. (2019) 273:197767. doi: 10.1016/j.virusres.2019.197767

106. Wang G-F, Shi L-P, Ren Y-D, Liu Q-F, Liu H-F, Zhang R-J, et al. Anti-hepatitis $\mathrm{B}$ virus activity of chlorogenic acid, quinic acid and caffeic acid in vivo and in vitro. Antiviral Res. (2009) 83:186-90. doi: 10.1016/j.antiviral.2009.05.002

107. Wittemer S, Ploch M, Windeck T, Müller S, Drewelow B, Derendorf $\mathrm{H}$, et al. Bioavailability and pharmacokinetics of caffeoylquinic acids and flavonoids after oral administration of Artichoke leaf extracts in humans. Phytomedicine. (2005) 12:28-38. doi: 10.1016/j.phymed.2003.11.002

108. Kaur R, Manjal SK, Rawal RK, Kumar K. Recent synthetic and medicinal perspectives of tryptanthrin. Bioorg Med Chem. (2017) 25:4533-52. doi: 10.1016/j.bmc.2017.07.003

109. Letko M, Marzi A, Munster V. Functional assessment of cell entry and receptor usage for SARS-CoV-2 and other lineage B betacoronaviruses. Nat Microbiol. (2020) 5:562-9. doi: 10.1038/s41564-020-0688-y
110. Müller C, Obermann W, Schulte FW, Lange-Grünweller K, Oestereich L, Elgner $\mathrm{F}$, et al. Comparison of broad-spectrum antiviral activities of the synthetic rocaglate CR-31-B (-) and the eIF4A-inhibitor Silvestrol. Antiv Res. (2020) 175:104706. doi: 10.1016/j.antiviral.2020. 104706

111. Jackwood M, Rosenbloom R, Petteruti M, Hilt D, McCall A, Williams S. Avian coronavirus infectious bronchitis virus susceptibility to botanical oleoresins and essential oils in vitro and in vivo. Virus Res. (2010) 149:86-94. doi: 10.1016/j.virusres.2010.01.006

112. Yin J, Li G, Li J, Yang Q, Ren X. In vitro and in vivo effects of Houttuynia cordata on infectious bronchitis virus. Avian Pathol. (2011) 40:491-8. doi: 10.1080/03079457.2011.605107

113. Lee J-H, Park J-S, Lee S-W, Hwang S-Y, Young B-E, Choi H-J. Porcine epidemic diarrhea virus infection: inhibition by polysaccharide from Ginkgo biloba exocarp and mode of its action. Virus Res. (2015) 195:148-52. doi: 10.1016/j.virusres.2014.09.013

114. Li L, Yu X, Zhang H, Cheng H, Hou L, Zheng Q, et al. In vitro antiviral activity of Griffithsin against porcine epidemic diarrhea virus. Virus Genes. (2019) 55:174-81. doi: 10.1007/s11262-019-01633-7

115. McCutcheon A, Roberts T, Gibbons E, Ellis S, Babiuk L, Hancock R, Towers G. Antiviral screening of British Columbian medicinal plants. J Ethnopharmacol. (1995) 49:101-10. doi: 10.1016/0378-8741(95) 90037-3

116. Nguyen PQT, Ooi JSG, Nguyen NTK, Wang S, Huang M, Liu DX, et al. Antiviral cystine knot $\alpha$-amylase inhibitors from Alstonia scholaris. J Biol Chem. (2015) 290:31138-50. doi: 10.1074/jbc.M115.654855

117. Yang Z, Wu N, Fu Y, Yang G, Wang W, Zu Y, et al. Anti-infectious bronchitis virus (IBV) activity of 1, 8-cineole: effect on nucleocapsid (N) protein. J Biomol Struct Dyn. (2010) 28:323-30. doi: 10.1080/07391102.2010. 10507362

118. Chen C, Zuckerman DM, Brantley S, Sharpe M, Childress K, Hoiczyk E, et al. Sambucus nigra extracts inhibit infectious bronchitis virus at an early point during replication. BMC Vet Res. (2014) 10:24. doi: 10.1186/17466148-10-24

119. Hsieh L-E, Lin C-N, Su B-L, Jan T-R, Chen C-M, Wang C-H, et al. Synergistic antiviral effect of Galanthus nivalis agglutinin and nelfinavir against feline coronavirus. Antiv Res. (2010) 88:25-30. doi: 10.1016/j.antiviral.2010. 06.010

120. Theerawatanasirikul S, Kuo CJ, Phetcharat N, Lekcharoensuk P. In silico and in vitro analysis of small molecules and natural compounds targeting the 3CL protease of feline infectious peritonitis virus. Antiviral Res. (2020) 174:104697. doi: 10.1016/j.antiviral.2019.104697

121. Kim H-Y, Eo E-Y, Park H, Kim Y-C, Park S, Shin H-J, et al. Medicinal herbal extracts of Sophorae radix, Acanthopanacis cortex, Sanguisorbae radix and Torilis fructus inhibit coronavirus replication in vitro. Antivir Ther (Lond). (2010) 15:697-709. doi: 10.3851/IMP1615

122. Ulasli M, Gurses SA, Bayraktar R, Yumrutas O, Oztuzcu S, Igci M, et al. The effects of Nigella sativa (Ns), Anthemis hyalina (Ah) and Citrus sinensis (Cs) extracts on the replication of coronavirus and the expression of TRP genes family. Mol Biol Rep. (2014) 41:1703-11. doi: 10.1007/s11033-014-3019-7

123. Lau K-M, Lee K-M, Koon C-M, Cheung CS-F, Lau C-P, Ho H-M, et al. Immunomodulatory and anti-SARS activities of Houttuynia cordata. J Ethnopharmacol. (2008) 118:79-85. doi: 10.1016/j.jep.2008.03.018

124. Zhuang M, Jiang H, Suzuki Y, Li X, Xiao P, Tanaka T, et al. Procyanidins and butanol extract of Cinnamomi Cortex inhibit SARS-CoV infection. Antiv Res. (2009) 82:73-81. doi: 10.1016/j.antiviral.2009.02.001

125. McDonagh P, Sheehy PA, Norris JM. Identification and characterisation of small molecule inhibitors of feline coronavirus replication. Vet Microbiol. (2014) 174:438-47. doi: 10.1016/j.vetmic.2014.10.030

126. Kim H-Y, Shin H-S, Park H, Kim Y-C, Yun YG, Park S, et al. In vitro inhibition of coronavirus replications by the traditionally used medicinal herbal extracts, Cimicifuga rhizoma, Meliae cortex, Coptidis rhizoma, and Phellodendron cortex. J Clin Virol. (2008) 41:122-8. doi: 10.1016/j.jcv.2007.10.011

127. Lelešius R, Karpovaite A, Mickiene R, Drevinskas T, Tiso N, RagaŽinskien $\mathrm{O}$, et al. In vitro antiviral activity of fifteen plant extracts against avian infectious bronchitis virus. BMC Vet Res. (2019) 15:178. doi: 10.1186/s12917-019-1925-6 
128. Yang $\mathrm{Z}, \mathrm{Wu} \mathrm{N}, \mathrm{Zu} \mathrm{Y,} \mathrm{Fu} \mathrm{Y.} \mathrm{Comparative} \mathrm{anti-infectious} \mathrm{bronchitis} \mathrm{virus}$ (IBV) activity of (-)-pinene: effect on nucleocapsid (N) protein. Molecules. (2011) 16:1044-54. doi: 10.3390/molecules16021044

129. Oh ES, Petersen KS, Kris-Etherton PM, Rogers CJ. Spices in a highsaturated-fat, high-carbohydrate meal reduce postprandialproinflammatory cytokine secretion in menwith overweight or obesity: a 3-period,crossover, randomized controlled trial. J Nutr Nutr Immunol. (2020). 15:1600-9. doi: $10.1093 / \mathrm{jn} / \mathrm{nxaa} 063$

130. El Sayed, SM, Hamdi H. Almaramhy HH, Aljehanis YT, Ahmed M. Okashah AM, et al. The evidence-based TaibUVID nutritional treatment for minimizing COVID-19 fatalities and morbidity and eradicating COVID19 pandemic: a novel Approach for Better Outcomes (A Treatment Protocol). Am J Pub Health Res. (2020) 8: 54-60. doi: 10.12691/ AJPHR-8-2-3

131. Hafez M H, Attia YA. Challenges to the poultry industry: current perspectives and strategic future after the COVID-19 outbreak. Accept Front Vet Sci. (2020) 8:11. doi: 10.3389/fvets.2020.00516
132. Sundararajan A, Ganapathy R, Huan L, Dunlap JR, Webby RJ, Kotwal $\mathrm{GJ}$, et al. Influenza virus variation in susceptibility to inactivation by pomegranate polyphenols is determined by envelope glycoproteins. Antiv Res. (2010) 88:1-9. doi: 10.1016/j.antiviral.2010.06.014

Conflict of Interest: The authors declare that the research was conducted in the absence of any commercial or financial relationships that could be construed as a potential conflict of interest.

Copyright (c) 2020 Attia, Alagawany, Farag, Alkhatib, Khafaga, Abdel-Moneim, Asiry, Mesalam, Shafi, Al-Harthi and Abd El-Hack. This is an open-access article distributed under the terms of the Creative Commons Attribution License (CC BY). The use, distribution or reproduction in other forums is permitted, provided the original author(s) and the copyright owner(s) are credited and that the original publication in this journal is cited, in accordance with accepted academic practice. No use, distribution or reproduction is permitted which does not comply with these terms. 